\title{
The Security and Prosperity Partnership And the Pitfalls of North American Regionalism
}

\author{
Alicja GluszeK*
}

\section{ABSTRACT}

The article aims to describe in detail the essence of the Security and Prosperity Partnership (SPP), interpreting it as an initiative to overcome disfunctionalities and shortcomings of previous international arrangements among the United States, Canada, and Mexico. The spp failed to deliver the results that its initiators had in mind; its outputs were limited in scope measured in terms of the issues tackled, joint policies, and regional regimes. It brought some policy integration into North America beyond economic issues, but did not transform itself into a regional governance mechanism that would bring about self-regulation norms and structures.

Key words: North American integration, regional governance, Security and Prosperity Partnership.

\section{RESUMEN}

Este artículo pretende describir detalladamente la esencia de la Alianza para la Seguridad y la Prosperidad en América del Norte (ASPAN), a la cual interpreta como una iniciativa para encubrir las disfuncionalidades y deficiencias de los acuerdos previos entre Estados Unidos, Canadá y México. La ASPAN no pudo dar los resultados que sus iniciadores tenían en mente; en realidad éstos fueron limitados si se miden en términos de temas abordados, políticas conjuntas y creación de regímenes regionales. Sí trajo consigo cierto grado de integración de políticas públicas en Norteamérica más allá de los asuntos económicos, pero no llegó a ser un mecanismo de gobernanza regional que incluyera normas y estructuras de autorregulación.

Palabras clave: Integración norteamericana, gobernanza regional, Alianza para la Seguridad y la Prosperidad en América del Norte.

\footnotetext{
* Post-doctoral fellow, Center for Research on North America, unAM, ala.gluszek@gmail.com
} 


\section{INTRODUCTION}

In 2005, the Security and Prosperity Partnership (SPP) emerged in the North American institutional landscape as a yet another device to organize and facilitate trilateral and bilateral relations with respect to the countries' economic and security interests. The creation of the SPP sparked many expectations and fears about the direction of regional integration because it seemed that the federal administrations were taking the initiative and had decided to play a more prominent role in governing the social and economic integration set in motion years ago. However, the sPP's organization and results proved wrong for both its opposition and supporters, exposing the various weaknesses of North American regionalism: 1) dominant power structures (at the regional, national, and bureaucratic level) that foster bilateralism rather than trilateralism; 2) a weak strategic vision or common ideology for successfully competing with neoliberalism as the basis for regional integration or with national socialistbased protectionism; and, 3) the lack of institutions to act as advocates of regional interests. Nevertheless, the results showed that not everything is gloom and doom, and, as in life, some aspects of regional politics do foster further policy integration without the political integration of the three states.

The Security and Prosperity Partnership of North America emerged in 2005 during the Waco summit. Three North American leaders launched the initiative, calling on their respective federal bureaucracies to seek greater and more intensive cooperation. In the beginning, it was heavily publicized and promoted in all three countries. In contrast, its tacit decline and final demise in 2009 passed unheralded, suggesting the decay of the SPP as a response to interdependence pressures and to relation-management shortcomings.

A lot has already been written about the causes and circumstances of the SPP's establishment and closure. It grew out of the structural changes in the global economy and security factors, including China's entry into the World Trade Organization (WTO) and subsequent growth, especially in the U.S. market -China replaced Mexico as a secondary U.S. trading partner-, and the September 11 attacks on the World Trade Center and the Pentagon. In addition, the spP was influenced by changes in U.S. geopolitical strategy and domestic homeland security policy (Leycegui Gardoqui, 2012: 124-129; Benítez Manaut and Rodríguez Ulloa, 2005: 78-96; Velázquez Flores and Schiavon, 2008). Therefore, from this perspective, the sPP can be seen as a result of the efforts of Mexican, Canadian, and U.S. business-oriented actors (trade and economy departments and firms operating transnationally) to increase regional economic liberalization and competitiveness and make them a priority for the three countries. At the same time, it can be perceived as an effort to deal with security-related 
externalities arising from the constructed economic integration of the North American Free Trade Agreement (NAFTA), like the massive increase in transborder flows, and unilaterally imposed stricter border and immigration measures after the terrorist attack. Scholars and even people who took part in the SPP have rarely analyzed the entrepreneurship, leadership, or power of particular individuals (for example, Presidents Fox and Bush or Minister of Trade Carlos Gutiérrez). Surprisingly, the decline of the SPP is usually ascribed to a personal decision made by President Obama, who did not want to continue projects initiated by President George W. Bush. The same was said of Mexican President Calderón and Canadian Prime Minister Harper and their disinterest in the SPP when they replaced President Fox and Prime Minister Paul Martin.

In my analysis, I want to determine other factors inherent to the sPP and to the management of bilateral and trilateral relations in the North American region in order to specify variables that made the sPP work for only a few years.

The article is structured as follows: the first part questions and tests popular beliefs about the SPP; the second describes the characteristics of the SPP as a management framework and analyzes the changes that it underwent between 2005 and 2009. The third part presents evidence that confirms two functions of the SPP (the governance mechanism and the dialogue/cooperation device), revealing that these aspects were always present, though with varying intensity over time with respect to different issues on the SPP agenda. Each part consists of two elements: description and evaluation.

\section{Theoretical and Conceptual Approach}

It is my opinion that the SPP was a management framework applied to bilateral and trilateral intergovernmental relations, which from 2005 to 2009 organized and shaped the way those complex relationships were handled. This framework had two functions: sometimes it operated as governance (the governing process), while at other times it was a mechanism for cooperation and communication.

The management framework concept refers to the style or method of organizing the time and work of the governments of Canada, the U.S., and Mexico, to promote and achieve their goals with respect to each other and North America. This concept relates to the ways the agenda (needs/interests and objectives) was shaped, how inputs were directed to achieve the objectives, which activities were chosen as part of the agenda, which methods of monitoring, evaluation, and measurement of advances were included, and how outputs of the process and their results were evaluated. It was also a method for planning, directing, implementing, monitoring, con- 
trolling, and evaluating joint or coordinated actions. Obviously, management frameworks focus on delivering desired change. Looking at the SPP as a management framework enables us to see its weak and strong points and determine the factors that contributed to its success and failure.

The management framework concept used here is strongly inspired by Leon Lindberg's theory of political integration (1970). Lindberg defines political integration as a collective decision-making process that not only covers making policy choices but also collectively implementing them. So he argues that it is not only about collective process but also about collective outcomes of this process when the decisions made together are binding. He also argues that there is a causal relationship between the system and organization of collective policymaking and political integration of a region.

This article analyzes the Security and Prosperity Partnership as a management framework in order to explain the fundamental aspects of international political processes: the mechanics and dynamics of political decision-making, the maintenance of diplomatic relations, and policy outcomes.

From the perspective of trans-governmental regional governance, the SPP can be seen as a set of mechanisms and relations among various levels of executives in three North American countries set in motion in order to establish common regulations aimed at strengthening security and improving competitiveness in the region as a whole.

From another angle, the spp can be seen as an instrument to build and maintain relationships at the regional level. Its aim was to structure and promote dialogue and cooperation (not regulations, as in the previous case), to improve inter-governmental understanding, to generate a sense of shared responsibility, and to prevent unilateral action that could harm other partners in the region.

How do these basic terms that can be applied to the SPP (governance mechanism and communication/cooperation devices) relate to each other? Governance is the process and activity of governing; it is intentional behavior that imposes ideational, behavioral, and institutional order (Rosenau and Czempiel, 1992; Bevir, 2012).

Cooperation, on the other hand, means working together to achieve any goal. Communication is an exchange of ideas, which does not necessarily involve convincing others of our ideas or making others think and act accordingly. Cooperation and communication are broader concepts than governance. Using power and imposing authority is inherent to governance, cooperation, and communication, though they are not power-free relations: they are not acts of governing, of displaying authority.

Cooperation/communication is part of governance, but not all cooperation/ communication aims to create order (patterned behavior, an arrangement of social positions, or the corresponding norms and ideas that endure over longer periods of 
time). Communication/ cooperation can serve practical, temporary, ordinary goals like working together during a disaster or to catch a criminal or build a bridge. Cooperation/ communication can be a component of order as a value, as a desired behavior, as a dominant practice, or even a formalized practice. Governance impacts human behavior by constraining and enabling people to act in a desired way. It provides an intended and effective self-regulation of the social system, but cooperation/ communication is not necessarily successful in pursuing its goals.

In this article, I argue that the spp documents as well as its actions prove its dual function and its nature as an intergovernmental relations management framework. We can find examples of the harmonization and regionalization of policies, but at the same time we can find periods and initiatives that were limited to commissioning research and exercises to prepare for a natural disaster.

The spp's complex nature made it difficult for North American academics to evaluate its meaning and place in regional processes. I propose criteria with which we can judge the sPp's achievements and failures. They correspond to each of its features: management framework, governance mechanism, and cooperation/communication device. First, I look at management practices with special attention to the principles and organization of the SPP's work to assess the following: whether they were legitimate and accountable processes, whether they functioned in more effective and efficient ways then previous arrangements, and whether they were able to achieve the aims of the partnership. After this, I focus on governance practices and their productivity and effectiveness by examining the outputs of the SPP process such as the origin and nature of documents produced (unilateral, bilateral, multilateral, trilateral, or legally, politically binding); further, I assess the rules with respect to their flexibility, scope, depth, and their impact on different social categories like bureaucracy, economic sectors, and population. Finally, the inputs are evaluated in terms of the results and outcomes they produced in the region and in particular countries. The next part of the article explores aspects of the SPP that encourage and strengthen dialogue and cooperation. I focus on networks and joint projects that, thanks to the SPP, emerged and grew. I describe how the spp enhanced and sped up interactions, how it generated new networks and established a regional norm and sectoral and problem-driven communication.

\section{Nature OF the SPP: Literature Review}

The first step is to analyze the critics of the spp and question their claims. Then, I will compare the claims with the facts related to the political process within the SPP, its decisions, functions, and results. 
The most prevalent attack on the SPP is for its informality, which limited the initiative's transparency and accountability. Critics claim that the sPP was not governed by legal procedures or by international legal agreements (Van Landingham, 2009; Preciado Coronado, 2009; Zamora, 2011). This is a partially valid point, because treaties did not guide the transnational actions of each country's representatives. However, they were limited by each governmental institution's internal regulations, so they were not acting without regulations.

It is worth mentioning that the biggest criticism of the sPp's informality, the constant accusation that the SPP is being handled behind closed doors, has not been made about bilateral initiatives between U.S. and Mexico, the U.S. and Canada, or Mexico and Canada, such as the Partnership for Prosperity, the Canada-Mexico Partnership, the Smart Border Accords, and the U.S. Canada Partnership Forum. This criticism seems absurd in the larger context of media and congressional scrutiny and the interest in the SPP compared to the attention that has been paid to many informal interactions and networks existing in the region. Furthermore, how can something be secretive when, immediately after meetings and conferences, the media reported on the proceedings?

The accountability in the spp involved ministers and federal officers who were responsible for their actions before their presidents and prime minister. The leaders of the three countries set up an agenda and a list of objectives each year. These guided how their secretaries, ministers, and expert working groups should function. Often the deliverables were also specified (Grant and Keohane, 2005). Federal government officials worked within the legal boundaries that divide legislative end executive powers.

Governments, especially the entities responsible for the prosperity aspect of the SPP, wanted to be more accountable and responsive to their stakeholders and constituencies. They made the effort to institutionalize this relationship by creating the North American Competitiveness Council to get feedback about the sps's performance. From a broader perspective, the partnership reflected a limited view of prosperity as existing solely in the economic sphere and not including aspects like social well-being and development. However, the three countries recognized that they should work with those who could be affected by their policies.

Although the SPP was an international political process, it was implemented by national governments (not foreign or international institutions), and government actions could still be controlled and evaluated just like any other measure taken by national authorities. They were hardly used with respect to the SPP in all three countries. ${ }^{1}$

\footnotetext{
${ }^{1}$ In all three countries only a few hearings were held to demand information about the spp and evaluate the administrations' work: in Canada, three hearings: Canada, $39^{\text {th }}$ Parliament, House of Commons, the Health Committee, June 4, 2007; Standing Committee on International Trade, April 24 2007; Standing Committee on International Trade, May 10, 2007.
} 
The criticism from the legislatures about informality and poor accountability could be read as a cry for more power rather than a legitimate claim that decisions made within the spp fall under the purview of sole or joint prerogatives of the legislature. Furthermore, there was nothing that prevented them from exercising their power to evaluate executive performance. In each country, hearings were held, and administration representatives were questioned.

Unfortunately, congresspersons never questioned one prevalent activity in the SPP: information sharing (for example, about airline passengers). They were preoccupied with issues like energy in Mexico, water in Canada, or superhighways in the U.S., which were supposed to be negotiated within the sPP. Meanwhile, they ignored issues that had a tremendous impact on civil rights, including exchanging information about citizens and non-citizens, that probably should be the subject of a treaty requiring legislative approval (Almazan, n.d.; Cámara de Diputados, 2006; House of Commons, 2007a; Congressional Record, 2007). This was what happened when the U.S. wanted information about the passengers flying from EU countries, and so they negotiated an agreement with the European Commission.

The second important criticism of the spp claims that the process was illegitimate and undemocratic (Ayres and Macdonald, 2012; Council of Canadians, n.d.).

In the United States, the spP was evaluated several times, but no hearing was solely dedicated to it: Hearing before the HR Committee on Science, February 15, 2006, An overview of the federal RED Budget for fiscal year 2007, p. 89; Hearing before the HR Committee on Homeland Security, July 14 and 25, 2005, The Secretary's second-stage review: re-thinking the department of homeland security's organization and policy direction; Hearing before the Subcommittee on Management, Integration, and Oversight November 15, 2005 and May 11 2006, СBP and ICE: does the current organizational structure best serve U.S. Homeland security interests?; Hearing before the Senate Committee on Foreign Relations, July 12, 2005, North American Cooperation on the border; Hearings before a subcommittee of the Senate Appropriations Committee, March 2005, April 20, 2005, and April 28, 2005, Department of Homeland Security Appropriations for Fiscal Year 2006; Full field hearing of the HR Committee on Homeland Security, July 20, 2007, The Western Hemisphere Travel Initiative: perspectives of a community on the U.S. Canada border; Hearing before the Subcommittee on National Security and Foreign Affairs, March 11, 2008, National security and Latin America: Challenges and opportunities on energy co-operation; Hearing before the Subcommittee on Security and International Trade, April 12, 2007, Pirating the American Dream: intellectual property theft's impact on America's place in the global economy and strategies for improving enforcement; Hearing before a subcommittee of the Senate Appropriations Committee, March 1, 2007, Commerce, Justice, science and related agencies appropriations for fiscal year 2008; Hearing before the Subcommittee on Emerging, Threats, Cybersecurity, and Science and Technology, October 27, 2009, Real-time assessment of the federal response to pandemic influenza; Hearing before a subcommittee of the Senate Appropriations Committee, May 13, 2009, Department of the Interior, the Environment, and Related Agencies Appropriations for Fiscal Year 2010; In the United States, the state governments expressed their will and demanded that the federal government cease the SPP process; the request were sent to the Senate by Idaho (Congressional Record, Senate, 2007b), Montana (Congressional Record, Senate, 2007a), Georgia (Congressional Record, Senate, 2008b), Utah (Congressional Record, Senate, 2008a).

In Mexico, immediately after the spp was announced, the Joint Foreign Relations and Foreign Relations (North America) Commissions demanded a study of the spr. Later legislatures sporadically called the principals of foreign affairs agencies and economy departments to testify (Cámara de Diputados, Centro de Documentación, Información y Análisis, 2010, 2008, 2007, and 2006). 
Again, this is a constitutional question about what types of matters require joint action by the executive and the legislature: what is the margin of autonomy in the government? How does the delegation work, and what issues should be negotiated with citizens even after elections?

Here, I would like to present an alternative view of the spp that has not been discussed and that gives us different arguments about the legitimacy of actions taken by the three heads of state and about the SPP accountability model based on the principle idea of modern democracies: the delegation of power.

Presidents Fox and Bush and Premier Paul Martin (and their successors) were democratically elected. The power to define state policy and govern was delegated to them according to the framework specified by their respective national Constitutions. In the three countries, the executive has different kinds and degrees of autonomy, and the Constitutions stipulate its legal boundaries. If someone says that their actions were illegitimate with regard to the spp or that they were not democratic or lacked accountability, they undermine the political systems of the United States, Mexico, and Canada. It is political opinion, not legal claim that ignores the principle of the delegation of power.

Many institutions that have participated in the SPP (federal agencies, departments and ministries responsible for public health, agriculture, energy, and trade) have no legally grounded responsibilities in the international arena. Their participation in the spp was delegated by the first executive in each country; so, their mandate emanates from constitutional prerogatives.

However the leaders made one questionable decision, which was to give a privileged position to the business community. They did this by establishing the North American Competitiveness Council and ignoring other interest groups that would be affected by their decisions (for example, border states) (Brodie, 2008; Gilbert, 2007; Healy, 2007). Nevertheless, in Mexico the consultation process was open to any civil society agent (SRE, n.d.); in Canada government officials also claimed to discuss issues on the SPP agenda with different stakeholders, but in fact the most active and warmly embraced by the governments was the North American business sector (House of Commons, 2007a, 2007b, and 2007c). This bias reflects a narrow vision of the ways prosperity and security are generated and guaranteed, as well as the power structures in the three societies. But also it reflects the pragmatic side of political processes and whether you want to have something done in a timely manner or you want to get stuck in constant negotiations with a broad range of interests. Within the SPP, the chief executives exercised great pressure to deliver results, which required compromises and prioritization. However, politicians and bureaucrats did not address all the wishes of big business. 
The other criticism and fear about the sPP relates to the claim that this process leads to the North American Union and to diminished national sovereignty (Almazán, 2007; Gonzalez Amador, 2007; Esquivel, 2005; Gafney, 2007; Judicial Watch, 2007; Luo, 2007; Savage, 2007; Barlow, 2005; Sandoval Palacios, 2008). This claim, however, completely ignores the fact that, thanks to the division of power as well as checks and balances, the power of each branch of government in the three countries is limited. It also disregards the facts about the activities within the spP.

In order to construct political and economic union, you need agreement between the executive and the legislative branches. In the meantime, with the spP the executive deliberately decided to reduce the scope and depth of its actions by limiting itself to constitutionally established prerogatives. There was no opportunity to pursue ambitious projects, because in order to undertake them, they would have to negotiate with the legislatures regarding the budget, domestic laws, and international agreements. To put it simply, they could talk about almost everything, but they could do little.

And this is manifested in the concrete actions taken by the three governments with respect to the SPP agenda, like protocols and cooperation in times of emergency caused by epidemics or natural disaster or pledges to protect intellectual property, though the latter were not taken as seriously in Canada as it was in Mexico and in the U.S.

The aforementioned criticism of the spp leads me to ask why anyone would think that democratically elected politicians would limit their power and their citizens' autonomy (otherwise known as state sovereignty) and surrender themselves and their countries to other actors such as foreign politicians and international corporations. I argue that this suspicion that presidents and government officials act against the will of the people of their respective countries by establishing and perpetuating the SPP emerges from doubts about the autonomy of politicians from the business elites in Mexico, Canada, and the U.S. (Chase, 2011; Savage, 2010; Wikileaks, 2009). They are also born of xenophobic stereotypes about other countries and their people. For example, the criticism of the spp in the U.S. was inspired by views that Mexico is a corrupt, violent, primitive society with which the U.S. should not be associated. The same prejudices about Mexico also persist in Canada, even though they were diplomatically hidden. Negative perceptions of U.S. Americans as being egotistical and obsessed with the capitalist ethos (rather than a sense of community and an appreciation of social policies) and post-9/11 limitations of civil liberties and rights were prevalent in the Canadian critiques of the spr. These negative sentiments and beliefs about the relations between politicians and the business sector and about North American neighbors heavily influenced the way the SPP was perceived. In consequence, the analysis and evaluation of the SPP were not based on facts but on fears and prejudice. 
The other false accusation against the SPP relates to the legal nature of the Waco declaration (Arley Orduña, 2012: 317-372). In the Waco declaration, U.S., Mexican, and Canadian leaders set up a process of communication and cooperation among multiple agencies and departments and called it the Security and Prosperity Partnership. It is not a treaty, and it does not have all the traits that a legal agreement among nations should have in order to be called a treaty (Villiger, 2009:77-79; Dorr and Schmalenbach, 2012:879; Corten and Klein, 2011:37-39, 211-212). Not all international agreements are treaties according to the Vienna Convention. A treaty must be concluded, which means it has to go through all the steps established by domestic law referring to treaties. In the case of Canada, the U.S., and Mexico, a treaty must be approved by the legislature. By not submitting the Waco declaration to the legislative vote, the first executives demonstrated that they did not want to treat the document as legally binding. Though it was written and signed by heads of state, there is no mention that the document is governed by international law (Corten and Klein, 2011: 41-42). It does not have provisions clearly stipulating the date when it enters into force. Furthermore, the Waco document is a political declaration that fits the description of the 1962 Memorandum from the un Office of Legal Affairs, which defined a declaration as "a formal and solemn instrument, suitable for rare occasions when principles of great and lasting importance are being enunciated."

However it must be added that the rhetoric of the declaration is misleading. For example, calling the process the "Security and Prosperity Partnership" evokes an entity, an organization. Nevertheless, the spp lacks elements that normally constitute an organization, like a charter with internal regulations and specified competencies. Calling it the SPP was a move addressed to bureaucracies and the media, not the expression of a will to govern in a new way and subordinate the signees to international law.

The last myth about the SPP is that it was a technical, depoliticized, and bureaucratized process. The spp was not in fact devoid of politics; it was a process where different constellations of power were set in motion (Grondin and de Larringa, 2009; Craik, 2011; Ackleson and Kastner, 2006). The first constellation was the power structure of the three economies and states; the second consisted of the bureaucratic machinery and inherent power relations already existing within them and new ones established by the spp; the last constellation was formed by the relationship between state and business actors.

Though there is a tendency to perceive the SPP as a depoliticized process run by experts working on technical issues because there was little involvement of legislatures and parties in the agenda-setting and decision-making process, this was not the case. The reality was much more complex due to the fact that national, institutional, 
and personal interests were present at domestic and intergovernmental negotiations, making the SPP a game of "politics as usual" rather than technocratic governance.

Often the literature about the spp has argued that countries' political elites colluded with business elites to jointly attempt to reorganize North America according to capitalist interests. In the meantime, the facts do not confirm harmonious relations between politicians and corporations. The North American Competitiveness Council, an auditory and consulting body established by the leaders of North America to accompany the SPP, often criticized the unresponsiveness and tardiness of the bureaucrats involved in the process. On the other hand, governments sometimes refused to implement their proposals.

What have been omitted in the SPP analysis are the consequences of its bureaucratic character. The SPP architecture created at least three layers of hierarchy that were far from cohesive and harmonious in terms of coordination (see Diagrams 1 and 2). First was the level of leaders and their staff (presidency, Privy Council, National Security Council), to whom coordinators of the partnership's two pillars, security and prosperity, reported on advances. These were the heads of the Ministries of Economy and of the Interior in Mexico, the Departments of Homeland Security and Commerce in the U.S., and the Ministries of Industry and Public Safety in Canada. Economic affairs and public security departments oversaw the performance of many federal institutions, like those responsible for agriculture, the environment, transport and communications, health, the budget and treasury, migration and border management, and energy. This created a third layer in the SPP, and federal institutions found themselves in weaker and more subordinate positions. Bureaucratic politics constrained the SPP process. The status of foreign affairs departments was ambiguous and changed over time from 2005 to 2006. They were supporting institutions, and later they gained more power in coordinating both pillars of the partnership and preparation of the North American Leaders Summits.

The stakes and interests of each federal institution involved in the spP in all three countries were different, and though it was not very politicized, it was not an entirely technical process devoid of power relations.

\section{The Ontology of the spp as a Management Framework For Trilateral and Bilateral Relations The Context: Previous Management Models and Their Criticisms}

The spP did not emerge out of nothing; long before 2005, both formal and informal inter-governmental networks were already shaping and organizing interstate and 
intergovernmental relations in the region. First, there were trilateral institutions based on NAFTA, the North American Commission for Environmental Protection (NAEC), and North American Commission on Labor Cooperation (NALC) like the Free Trade Commission, the Commission on Labor Cooperation, the Commission on Environmental Cooperation, and various working groups and committees (see Table 1) (Torres, 2005; Anderson, 2008; Vega Canovas, 2010a). There were other trilateral bodies like the North American Energy Working Group (since 2001) and the North American Biotechnology Initiative (since 2003).

Bilateral networks and cooperative arrangements were in existence: for example, the U.S.-Canadian North American Aerospace Defense Command (since 1958), the U.S.-Mexican Binational Commission (since 1981), the Border Vision Initiative mechanisms (1997), the Canada-U.S. Partnership Forum (1999), and coordination and collaboration mechanisms based on smart border agreements (since 2002, focused on security related issues). They emerged from two initiatives: the Canada Mexico Partnership (since 2004) and the Partnership for Prosperity of the U.S. and Mexico (since 2001) (Barry, 2003; Bailey and Guillen Lopez, 2009).

Besides cooperation frameworks, the three countries' relations were institutionalized in a very specific and formal way by procedures of conflict resolution based on NAFTA Chapters 11, 19, and 22 (Vega Canovas, 2005; Morales, 1999).

Before the SPP, a dense web of interactions and relations already existed to discuss, resolve, and work together on North American issues. Their effectiveness and efficiency in solving emerging problems and disputes were questionable. They were also too weak to prevent violations of existing treaties by any of the countries except what was most important to the U.S. And as the past proved, unilateral, shortsighted, politicized perspectives remain a constant threat to the regional legal foundations and undermine the trust needed to build a common future (Clarkson, 2008).

The instruments and mechanisms available to the three countries were bureaucratic, too formal, not flexible enough, and unresponsive to changing contexts. They were also politicized and time-consuming (Clarkson, 2008; Vega Canovas, 2010a; Capling and Nossal, 2009; Alba, Proud'homme and Vega Canovas, 2007). They perpetuated the national logic and did not give any chance to voice and defend the regional, North American perspective that would be independent from political tradeoffs, but based on the research and dynamics of integrated economies.

These intergovernmental institutions' shortcomings were exposed and attempts were made to fix them and move forward with the North American integration project (see Table 2).

In early 2000, lots of ideas for North America were circulating to inspire leaders to make bold strategic moves. The Mexican government and Canadian businesses in 
particular expressed wishes for a deeper and broader integration of the region (Wikileaks, 2003; Clarkson and Banda, 2004; Daudelin, 2003; Capling and Nossal, 2009; Brodie, 2012). Academics from the three countries also took a stand in the face of the erosion and deficits of regional governance (Pastor, 2001; Chambers and Smith, 2003; Hakim and Litan, 2002; Canadian Council of Chief Executives, 2003; Hughes, 2005). The tenth anniversary of NAFTA created momentum and a pretext for producing and debating alternative scenarios for the future of the continent (De la Reza, 2004; Weintraub, 2004; Nevaer, 2004; Aspe, Weld, and Manley, 2005; Hufbauer and Schott, 2005; Hughes, 2005; Noble, 2005; Cortés Campos, 2005). An effort was also made within the Mexican and Canadian governments to invent new approaches to cooperation in a bilateral or trilateral framework, respectively, the whole enchilada or the Vision 2020 proposal, and the common security perimeter initiative or recommendations made by the House of Commons Foreign Relations Committee in its report Partners in North America. Advancing Canada's Relations with the United States and Mexico (2002).

The Security and Prosperity Partnership emerged in this historic setting out of frustration over pre-existing mechanisms of cooperation, dialogue, and dispute resolution, as a new approach to managing relations (Celorio, 2005; Sands, 2006; Gutiérrez Fernández, 2005). Of course, U.S. Americans, Mexicans, and Canadians also had a larger picture in mind: the state of regional competitiveness in the global economy and asymmetrical threats to public security. They were especially concerned about negative effects of U.S. security policy on trade operations and the national economies. They were also aware of China's rapid rise in the world economy, and at the same time of the outdated NAFTA provisions, non-trade barriers that remained in place though the customs duties had been lifted (Leycegui Gardoqui, 2012; Rozental, 2006; Anderson and Sands, 2007; Garcia-Segovia de Madero, 2003; Benítez Manaut and Hristoulas, n.d.; Cespedes, 2008; Velazquez Flores and Schiavon, 2008). In the eyes of the leaders and their advisers, the existing bilateral and trilateral institutions could not deal with these issues or were too slow in their reactions. A new model of addressing common problems was needed.

\section{The spp in Response to the Institutional Shortcomings Of North American Integration: Properties and Internal Dynamics}

The spP was created in 2005 by the chief executives of the U.S., Canada, and Mexico in response as much as to the global economic and security situation as to the shortcomings of existing institutions and to the leaders' personal legacy concerns. The SPP 
was also designed to circumvent any political discontentment and opposition -as such, it was a response to domestic political, legal, and cultural constraints- and in the belief that the challenges that North America was facing could be resolved within executive powers and technocratic capabilities.

Since 2005, the SPP has changed over time as leaders' involvement and attention faded away. The intensity of cooperation dwindled, and the agenda shrank. The story of the SPP is a story of slow decline, not of a rise toward regional governance. The very hopeful and ambitious beginnings in 2005 and 2006 were followed by drifting in 2007 and 2008 and the program's unannounced death in 2009.

Aside from the aforementioned changes in the sPP lifespan, there were also differences in the effectiveness and cooperation model for its two pillars, prosperity and security, as well as among various working groups. For example, on the security side, there were more work, and technical collaboration and dual bilateralism were upheld. On the prosperity side, more policy documents were produced, accompanied by the coordination of unilateral actions. The sphere of prosperity was also characterized more often by a trilateral approach.

Trying to define and describe the SPP is a difficult task because finding general traits and patterns of behavior applicable to the whole agenda is almost impossible. It is even harder to evaluate the sPP and avoid oversimplifications. There is tendency to call it a failure, but the reality is more complex and a grey area.

The spe did not address all the shortcomings of the North American institutional framework (politicization, weak law enforcement, bureaucratization). Three leaders decided to proceed with the SPP and put aside the NAFTA system's trade conflicts and institutional weaknesses with the knowledge that any greater reforms required action from the legislatures. They would eventually need a lot of time when the situation demanded quick responses.

Furthermore, the relationship between already existing mechanisms of cooperation and governance and the SPP was also left untreated and unresolved in informal or formal ways. In consequence, those who participated in the sPp had to handle multiple mechanisms and agendas that as a result debilitated their chances of success in the SPP.

In many ways, the sPP was a continuation of old patterns and plans of action. Once again, the chief principals met, discussed, and published joint statements or political declarations. Once again, experienced working groups met, but did not accomplish much. Once again, the business community to whom much was promised was getting more and more frustrated each year reiterating the same recommendations and receiving few tangible results. Again, Canada and Mexico tried to limit their neighbor's unilateralism; and they learned that it is not so easy to do, because not only can the U.S. Congress cause problems, but uncoordinated executive agencies 
can also act against the regional interests pronounced at the sPP meetings. For example, in case of Canada, the U.S. Department of Homeland Security created the Western Hemisphere Travel Initiative, which discriminated against Canadian travelers who did not have passports to cross the U.S. border, as if commitment to spP priorities did not exist. In case of Mexico, under the SPP, transportation and trucking were debated, but the big elephant in the room, the "dispute over the access of Mexican trucks to U.S. soil," put aside. ${ }^{2}$ That said, it is clear that the sPP was a continuation of the power structure among the three countries that evolved from its patterns of cooperation and communication practices.

Despite the fact that the SPP resembles many other management frameworks already functioning in North America, there was an effort to improve effectiveness and speed up political cooperation. The novelty of the SPP's organization lies in the involvement in its structure of each country's highest level of power. ${ }^{3}$ It was intended to break the bureaucratic (formal, lengthy, non-innovative) character of previous frameworks, because with the interest and attention of the leaders and their staffs, administrations work more effectively and quickly. The spe created a hybrid organization that included both a network and a hierarchy.

This new type of organization represented an advance toward greater effectiveness, but it also became the SPP's weakness. Since the agreements reached through the SPP were non-binding declarations, only one way existed to demand action from bureaucracies, and this involved putting pressure on countries to comply (Interview with Mexican government officials, 2012; Roff, Krajnc and Clarkson, 2009; Craik, 2011). ${ }^{4}$ In the absence of that pressure, the bureaucrats lost the motivation to make an extra effort, and the whole the SPP began to drift in the inertia of the old habits of diplomatic exchanges and periodic meetings that ended without specific and operationalized policy initiatives.

When at least one leader loses his / her interest in the SPP, the whole initiative gets a lower profile in the hierarchy of priorities. In consequence, the morale of other administrations can be affected. Since the U.S. exercises hegemony, when the president stops investing energy and capital in the SPP, the whole endeavor ceases to function.

\footnotetext{
${ }^{2}$ After years of non-compliance with international arbitration and discussions with Mexican officials, the U.S. government set up a trial program in 2007. Mexican trucks finally gained access to U.S. territory via the joint action of Congress and President Obama, who signed the bill for this pilot program, which then was canceled in 2009.

${ }^{3}$ For more about the origins of the spP and the crucial role of a few people in White House's National Security Council, in Mexico's President's Office, and Canada's Privy Council, be read the master's thesis written by Steven Masson, “Upgrading North American Architecture through the Security and Prosperity Partnership" (n.d.). Interviewed Mexican officials also pointed out on many occasions that pressure from the chief executive office was very important in the first years of the SPP.

${ }^{4}$ All interviews were conducted in confidentiality, and the names of interviewees are withheld by mutual agreement.
} 
In fact, this is what happened. Between 2005 and 2006, the oversight and pressure of the White House National Security Council, Canada's Privy Council, and Mexico's President's Office sped up domestic and international negotiations within the SPP, and the deliverables were impressive. ${ }^{5}$ Since 2007, when both President Calderón and Prime Minister Harper demonstrated that the SPP and trilateralism were not among their priorities, the sPp begun to be managed by foreign relations departments and ministries instead of by the leaders' close collaborators. In effect, the spp involved more discussion and meetings than actual policy-making or policy implementation. Later on, when President Obama did not want to continue policies of his predecessor, the SPP was dropped from the agenda.

As mentioned above, the spp suffered from some management shortcomings, the most pervasive of which was related to the way SPP work was planned. In previous management frameworks, the work was driven by a series of meetings. Though this was supposed to be a strength, making the SPP a more flexible and responsive mechanism, it actually plunged it into a series of undefined situations. In the beginning, lots of issues were on the agenda, but after two years they shrank to four or five. The agenda set by the leaders was always formulated broadly, without giving the respective bureaucracies specific guidelines or practical expectations (Partnership of North America, 2006; U.S. General Printing Office Presidential Documents, 2005, 2007a, and 2008). The leaders gave them a list of needs to be satisfied, expecting that something would be done, that pressured the bureaucracies. The coordinators of the security and prosperity agendas were responsible for clarifying and specifying goals, but they were vague in their recommendations (Government of Canada, 2005, 2007; U.S. Department of Commerce Archives, 2008a).

The bureaucracies of each country held long discussions, went on fact-finding missions, and shared information in order to find out what needed to be achieved to overcome challenges such as greater competition, safer borders, energy security, etc. Also during much of their joint work, they focused on defining vague concepts like security, prosperity, and quality of life in the North American context, and they discussed the domestic interests and capabilities of their respective federal agencies. This effort, though commendable, consumed a lot of time and made the spp less effective.

Besides the broad, vague agenda and poorly specified goals, yet another problem was posed by weak monitoring and evaluation mechanisms. The benchmarks and indicators of success were not well defined. For example, meetings and conferences

\footnotetext{
${ }^{5}$ Of course, many of the spp outputs during that period were low hanging fruits. Later on, new ideas and solutions had be discussed, which required time and therefore slowed down the spp between 2007 and 2009. This was attributed to Canada's lack of interest in Mexico and the fact that new proposals needed time to mature.
} 
were considered deliverables when the strategic objective was competitiveness or security and the tactical aims were harmonization of regulations or elimination of obstacles. Reports on the spP cited its accomplishments and achievements. However, the reports suggest that planning in the long and short term was chaotic.

Another weakness that did not help the spp live up to its ambitious aims was its lack of a proper budget. Only the U.S. and Canada requested financing for projects related to the SPP; Mexico made a tacit pact not to ask Congress for funds explicitly earmarked for sPP projects (Department of Finance Canada, 2008 and 2006; U.S. Senate, 2005a, 2006, 2007, and 2009; U.S. Government Printing Office, 2006).

In the sphere of regulation, an important part of spp cooperation, it was argued that money was not so necessary for introducing changes related to modernization and the expansion of the border structure. However, it is obvious that when you want to introduce new policies or strengthen the execution of existing ones, you need funds. By not making any financial commitments, the leaders and their ministers limited the chances of success, again sentencing the spp to be less productive and efficient.

Another spp feature relates to how the North American agenda was treated by the governments, whether trilaterally or bilaterally (continuing the pattern of dual bilateralism). The researchers recognized three basic relationships in the region: U.S.-Mexico, U.S.-Canada, and Mexico-Canada, and they stressed that the trilateral relationship was still in statu nascendi (Clarkson and Banda, 2004; Pastor, 2005; Capling and Nossal, 2009). The spp confirms the structural and historical tendencies of three distinct relationships rather than embodying a dramatic change in the trilateral love affair.

By reiterating the trilateral dimension, sPP events and documents tend to obscure the deeper reality of spp negotiations regarding both pillars of the agreement: prosperity and security. Almost all discussions about security, except health security and emergency preparedness (which were held both bilaterally and trilaterally), were convened bilaterally (US Department of Commerce, 2007; SEMARNAT, 2012; COFEMER, 2013; IFAI, 2013, US Senate Committee on Foreign Relations, 2005). To the contrary, the prosperity agenda was managed more trilaterally. However, some issues only interested Mexico and others were only important for Canada. As a result bilateral negotiations reflected the discrepancies among the three countries' the interests and visions (Interview with Mexican government official, 2012; Wikileaks 2005a, 2005b, 2005c).

Often, when leaders and those responsible for the spp met, they did not hold trilateral meetings. Instead the U.S. delegation held separate meetings with Mexico and Canada. In addition, if we take into consideration that many activities within the partnership framework were temporary (exchange of information, modernization of border infrastructure, management of border/transit programs, exercises and trainings), these collaborative efforts were practically all bilateral. 
Another feature of the SPP was that it did not produce formal procedural guidelines or internal regulations. Those involved in it preferred proceeding this way because it helped them focus on getting things done and avoiding long negotiations on procedural arrangements. However, there was a consensus about the following principles that organized their work:

1. Refrain from actions that require the legislature's approval (Interviews with Mexican government officials, 2012);

2. Consult stakeholders, especially the business community; ${ }^{6}$

3. Pursue solutions based on research and / or that have been tested; ${ }^{7}$

4. Three can talk; two can do (bilateralism is acceptable, everything does not have to be discussed and done trilaterally); ${ }^{8}$ and

5. Start from "low hanging fruits," and then move on to new issues and search for new solutions (Anderson and Sands, 2007; Martin, 2005; Moens, 2011, interview with Mexican federal government officials, 2012).

The first, fourth, and fifth principles focus on issues that are feasible and, in consequence, speed up cooperation. Principles two and three helped the three countries to achieve: 1) better-informed decisions made with access to the resources in other countries; and 2) greater transparency and predictability of regulatory practices that contribute to their expertise and promote best practices internationally, thus influencing standards elsewhere.

In relation to the inputs (human and financial resources, power relations, bureaucratic constraints, organizational structure), the SPP was very effective. It over-

\footnotetext{
${ }^{6}$ All official spp websites posted an invitation to private and non-profit organizations to participate in consultations about the SPP process. Respect for the business sector was institutionalized in the form of the North American Competitiveness Council, and also in the regular meetings of working group participants who sought advice and recommendations from stakeholders. This evidence was found, for example, in the records of the hearing before the Health Committee on June 4, 2007 in Canada's 39th Parliament and was confirmed by my informants in Mexico who recalled that Mexican governments organized meetings with business leaders and academics..

${ }^{7}$ The spp launched a couple of pilot projects to test new solutions and collaborative measures: evaluation of the the spp NA Pilot Project on Reducing Emissions from Vehicles and Engines http:/ / www.ec.gc.ca/ doc/ ae-ve/2011-2012/1405/ec-com1405-en-es.htm; the Nexus Marine Pilot Project Evaluation Study http:/ / www.cbsa-asfc.gc.ca/agency-agence / reports-rapports/ae-ve/2006/nexus_mar-eng.html; the Trilateral Committee on Transborder Data flows ordered a survey on the negative effects of national regulations on transborder data flows http:/ / www.ic.gc.ca/eic/site/ecic-ceac.nsf/eng/h_gv00520.html; Another study ordered by the SPP analyzed border infrastructure and the capacity of border agencies on the U.S.-Mexico border. It was developed by the Colegio de Frontera Norte, and the report was published in 2007 "U.S.-Mexico Ports of entry: a capacity analysis and recommendations for increased efficiency."

${ }^{8}$ See the footnotes 39 and 40 (cfr. Moens, 2009; Ackleson and Kastner, 2006: 207-232, Capling and Nossal, 2009 ; Nossal, 2010).
} 
came a lot of deficiencies and managed to deliver some tangible outputs and results. However, compared to the complex needs and its ambitious goals, the spp's accomplishments are not impressive. This is due to the problems with translating the broad strategic needs into operational goals, defining measurable indicators of success, and implementing weak evaluation practices. Also, the partnership was affected negatively by shortcomings in leadership.

\section{The spp: Cooperation/Communication Device And Regional Governance Mechanism}

It appears that one of the foundations of the SPP was a belief that a deeper understanding and knowledge of each other was crucial for moving on with the North American project. A lot of energy and resources were employed to strengthen and maintain communication and cooperation toward a common vision of which challenges North America was facing as an economic region and security space. The list of accomplishments for the SPP and those who participated testify to the fact that many conferences, presentations, discussions, and exchanges of information were held.

In essence, there was too much talk, but not enough negotiating and decisionmaking. As Canadian officials discussed in 2007, "We're not at all at a stage of making any changes to regulations or anything. We're basically at the stage of comparing approaches in the three countries, identifying differences where there are differences, and, where appropriate, trying to remove the differences" (Chaput, 2007).

Efforts included conferences, meetings, and sessions on each country's legal framework. Representatives assessed how differences in each country's regulations are harmful for the trade or regional security of another. They also discussed what practical opportunities existed for improving that situation and whether it was possible to do this with unilateral action, a memorandum of understanding, or by treaty. ${ }^{9}$ During these learning meetings, best practices were shared and some were later implemented in other countries or tested in joint exercises (Secretaría de Economía, 2006a; Industry Canada, 2010; Martínez Bejarano, 2012; Legorreta Odorika, 2012).

If we study the evolution of some the spp initiatives, it becomes clear that many hours were spent on communication and building a common vision. However, they rarely led to formal negotiations, political declarations, or legal agreements (which

\footnotetext{
${ }^{9}$ This interpretation of the SPP as another model of international cooperation, not a form of regional governance leading to integration, is also argued by Jimena Jiménez in "The Security and Prosperity Partnership: Made in North America Integration or Co-operation?" in Julián Castro Rea, ed., Our North America: Social and Political Issues beyond NAFTA, University of Alberta Press, 2012.
} 
are indicators of policy integration). For example, the story of e-commerce cooperation demonstrates the usual practice of the SPP. In 2005, the three countries produced the Framework of Common Principles for Electronic Commerce and committed to national action plans consisting of reviews of existing law, exchanges of good practices, and consultations with the business sector. In 2008, they published a joint Statement on the Free Flow of Information and Trade in North America, and in 2009 they established the Trilateral Committee on Transborder Flow of Data to work on regional responses to facilitate and secure data flows. During its short life, the committee commissioned a study on private sector needs regarding data-flow regulation. It also organized conferences and workshops to disseminate knowledge of each country's regimens. This case illustrates how much time was needed to address the 2005 promise to better regulate and harmonize electronic data transfers in business environments. It shows once again how slowly the three bureaucracies operated together and how difficult it is to harmonize regulations or create a regional regimen.

Of course, the SPP was not a perfect communication device; the coordination at the domestic and intergovernmental level of people working on the security agenda and those working on the prosperity agenda was far from ideal. They often did not know who was collaborating on other projects (Interview with Mexican federal government officials, 2012; House of Commons, 2007a). This compromised the cohesiveness of their endeavors. However, the sPP was a necessary effort that sometimes successfully coordinated a complicated agenda to promote economic integration (Interview with Mexican government official, 2012). Those participating in the SPP were also conscious of the complexities of North American integration and of issues of interdependence.

In 2005, the leaders created several working groups within the sPP (see Table 1). Informal networks of officials from the three countries met cyclically and kept in daily contact with each other. During the SPP, additional working groups and forums were created, like the North American Competitiveness Council, the North American Aviation Trilateral, the Trilateral Committee on Transborder Data Flows, and the Laboratory and Surveillance Technical Working Group.

The partnership promoted cooperation and communication in North America by including provisions to promote greater dialogue in the many agreements it produced, among them, the Memorandum of Understanding between Canada and the U.S. It enhanced and strengthened the exchange of information and cooperative activities on public health and safety protection related to the safety of consumer products. The U.S.-Canada agreement enabled the simultaneous exchange of information between virtual national laboratory networks. The United States and Mexico signed an agreement to create advance notifications when consumer goods violated 


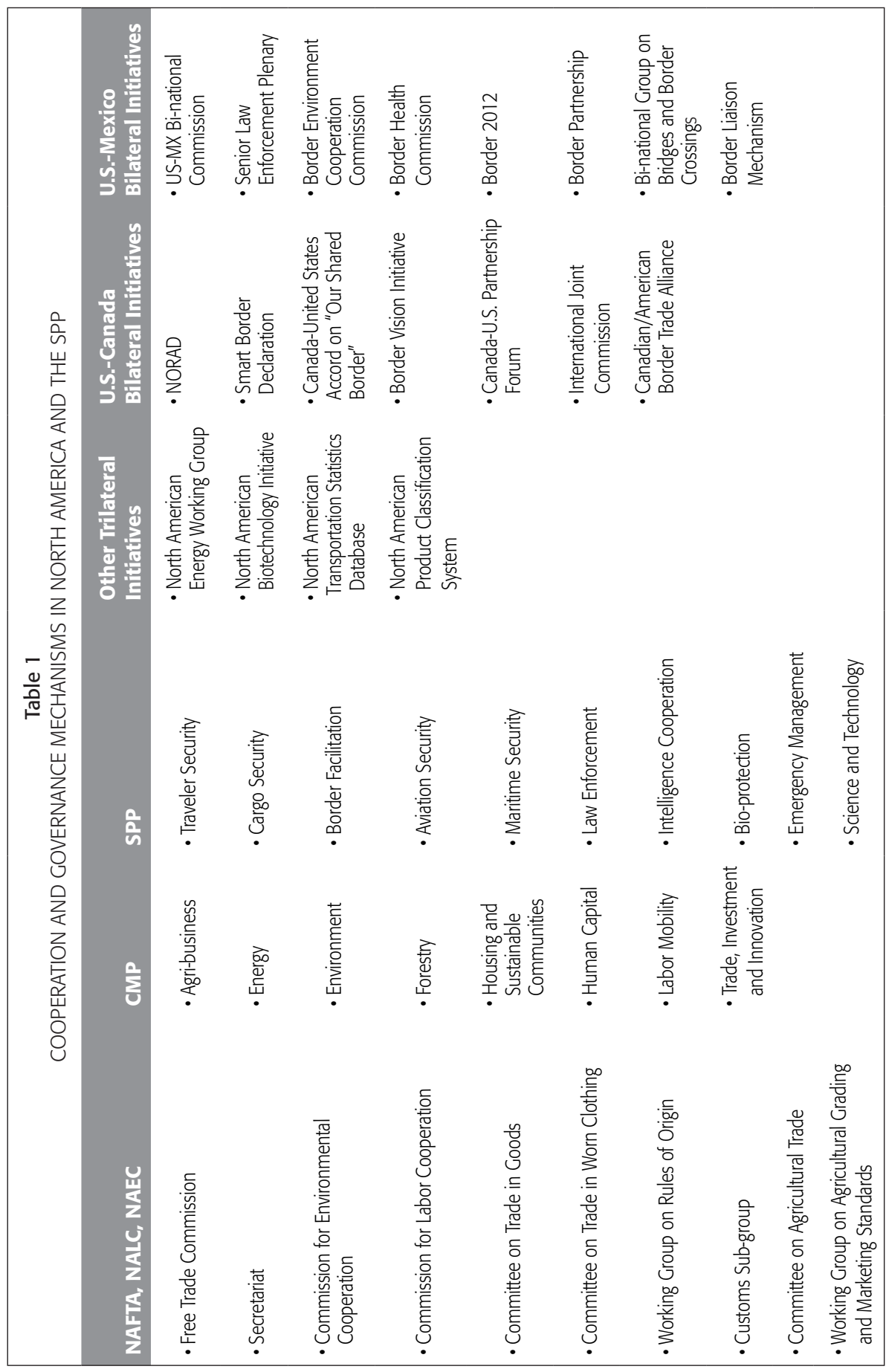




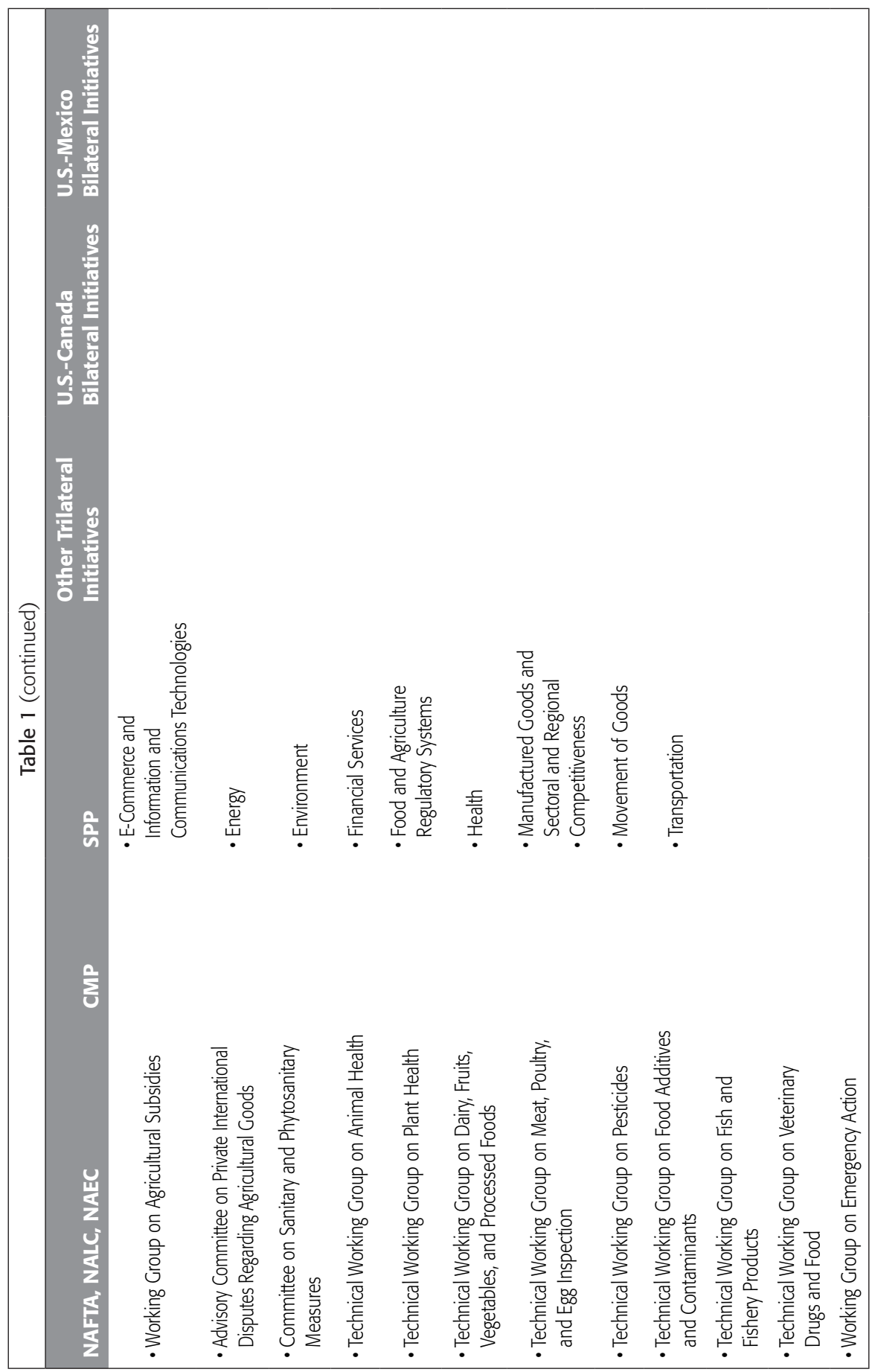




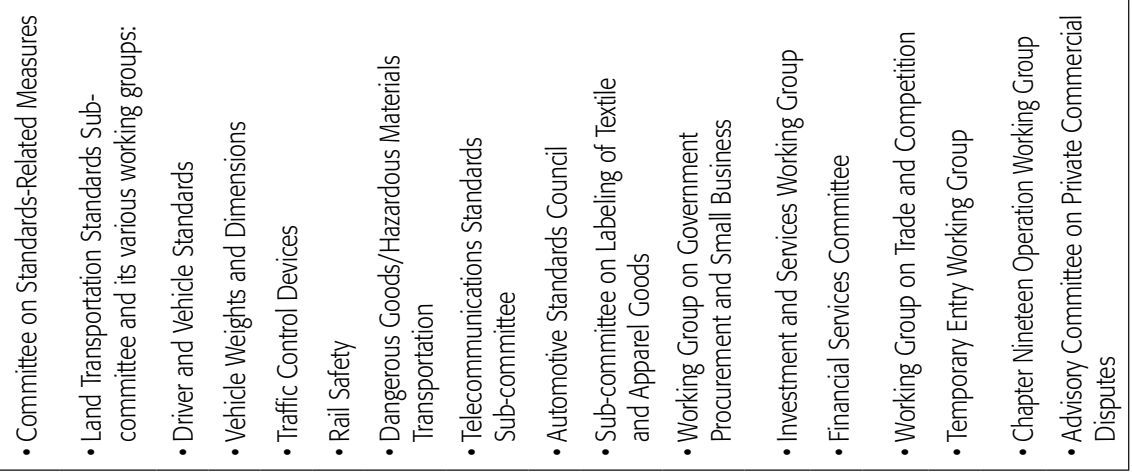


one country's safety standards or posed a danger to consumers. The U.S.-Canada agreement was a milestone in pipeline regulatory cooperation that increased compliance on data sharing, staff exchanges and joint training (Government of Canada, 2005; Secretaría de Economía, 2006a; U.S. Department of Colmmerce Archives, 2008b; Savage, 2010).

The spe promoted routine communication and cooperation and the exchange of liaison officers and fostered the maintenance of their posts abroad. For example, representatives from all three countries' public health agencies participated in an exchange. The National Targeting Center (NTC) in the United States and the National Risk Assessment Centre (NRAC) in Canada also exchanged officers.

Examples of the important role of the spP as a device for enhancing communication lived on even after the partnership ceased to exist. For example, some of the networks remained in operation or even expanded. In 2011, the U.S. and Canada formed the Regulatory Cooperation Council and signed another initiative, Beyond the Border, which represented a shared vision for perimeter security and economic competitiveness. Mexico and the U.S. also established the High Level Regulatory Cooperation Council and developed broad networks for the implementation of the Mérida Initiative (White House, n.d.; Savage, 2011a, 2011b). Participants who worked on the SPP North American anti-pandemic framework continued operating, and in 2012 they published an updated strategy. Probably the SPr's biggest achievement in terms of promotion of regional cooperation and dialogue is the institutionalization and survival of the North American Leaders Summit. This forum, though not very productive and appreciated by the leaders themselves, provides a guaranteed opportunity to meet with the U.S. president, whose time is precious and limited, an opportunity that many might be jealous of (Interview with Mexican government official, 2013).

The most basic type of cooperation was mutual assistance in law enforcement. The spr increased the intensity of information and intelligence exchange related to combating terrorism, money laundering, and people smuggling.

Often the partnership's programs were developed to test new solutions before they were applied. Another category of cooperation refers to pilot projects, like the Canada-U.S. land pre-clearance pilot at the Thousand Islands Bridge, the NEXUs-Marine pilot in Windsor-Detroit, and the Pilot Project on Reducing Emissions from Vehicles and Engines. These were exploratory programs to strengthen trust and to test new technologies and operational arrangements.

Some types of collaboration were temporary, and the countries used them to run joint assessments and evaluations. For example, the Canada-U.S. Public Security Technical Program completed a comprehensive Coordinated Risk Assessment, and the Integrated Border Enforcement Team also ran the Threat Assessment. Canada, 
Mexico, and the United States undertook a comprehensive analysis of various emissions inventories and tested emissions estimation methodologies for nine energygenerating facilities. Temporary cooperation efforts were carried out during natural disasters: the U.S. helped Mexico in 2007 during the floods in Tabasco and Chiapas, and Mexico helped the U.S. during the 2007 California wildfires. Other short-term cooperation took place when Canada and the United States worked together with Mexico to provide technical assistance and training opportunities as Mexico built a Bio-Safety Level-3 National Laboratory for inclusion in the Health and Human Services / Center for Disease Control Laboratory Response Network.

This last example was a case of international technical assistance. Similar cooperation occurred when the U.S. pursued greater nuclear detection and safety in cooperation with the governments of Canada and Mexico. It carried out a program called the Mega Ports Initiative (El Universal, 2007; U.S. Department of Commerce, 2008b; U.S. GAO, 2012). Thanks to this program, the U.S. provided and placed radioactive detection equipment in Mexican and Canadian seaports where the majority of goods enter the region. Other examples of this kind of cooperation involved bilateral projects such as the Canada-U.S. Chemical Assessment and Management Program (EPA, 2008a, 2008b), a five-year program to harmonize automated commercial information systems, and the U.S.-Mexico Alien Smuggler Prosecutions Program, a pilot program in El Paso and Chicago for the safe, humane, and orderly repatriation of Mexican nationals (Government of Canada, 2005).

Within the SPP, another form of cooperation developed that had a strictly technical, practical, limited scope of action. I am referring to joint policing of the U.S.-Canadian border. Other examples of collaborative initiatives included the Shared Cruise Ship Inspections Project, the joint verification of vessels entering the St. Lawrence Seaway.

Though it may appear that communication and cooperation in the spe went smoothly, this was not always the case. For example, between 2005 and 2007, Canada and the United States negotiated an initiative to modernize and expand border infrastructure for the Ontario/ Buffalo Peace Bridge and for the possible joint administration of a new port of entry. The two parties could not agree on a series of issues. As a result, the DHS dropped out of the talks (U.S. GAO, 2008).

The spp was rarely a forum for making rules. A review of its outputs demonstrates that the three countries agreed to introduce or promote general all-encompassing rules that were successfully implemented only a few times.

Some analysts interpret the SPP as a form of regional governance (Kirton and Guebert, 2010; Roff, Krajnc, and Clarkson, 2009; Anderson and Sands, 2007; Belanger, 2010; Gilbert, 2007; Grondin and De Larrinaga, 2009). The policy-making process can be understood as a sequence of stages: 1) problem identification, 2) agenda setting, 3) policy 
formulation, 4) policy adoption, 5) policy implementation, 6) policy evaluation, and 7) policy change or termination. These analyses ended up examining only the first four stages while overlooking whether the spP policies were implemented or not. I argue that even if the intention of sPP statements was to establish governing principles for the region, it still needs to be proved that the administrations followed up the declarations and acted upon them.

If the SPP had worked as governance device, it would be easy to determine its influence. It is difficult to link decisions made by the SPP with specific policy changes in any of the three countries. Because the partnership functioned in concert with other mechanisms such as Smart Borders Cooperation, NAFTA institutions, and the CanadaMexico Partnership, it is complicated to define its influence. How can it be separated from the influence of other political processes? One oft-cited spr accomplishment is the changes in rules of origin, a development actually produced by the negotiation process set up by NAFTA. Another accomplishment publicized in SPP materials is the border infrastructure upgrade, which was a continuation of the Smart Border agreements.

In conclusion, the SPP regulated bilateral and trilateral relations rather than regulating issues on the SPP agenda. However, at some point it also functioned as a governance mechanism that shaped the lives of people in North America.

The spp bureaucrats were aware of the institutional and cultural constraints of their actions. They knew that they were limited not only by domestic appetites and preferences but also by other international legal obligations. They reached formal, legal agreements only when they were sure that it would be accepted by the legislature. They were limited to making small, incremental steps like increasing and normalizing the hours of operation of border and customs agents

The rules and principles expressed in spp documents had different origins. Some were taken from multilateral recommendations or treaties, while others were developed by the SPP in a regional context or as a result of the acceptance of U.S. standards. For example, in the case of electronic data flows and intellectual property protection, the SPP referred to OECD or WTO recommendations. In the matter of natural disasters and public health emergencies, the three countries created mechanisms, protocols, and action plans related to North American circumstances. In many instances, especially in the sphere of security, Mexico and Canada had to adjust to U.S. standards; for example, the regulations related to the flow of people and goods across both borders.

The regulations, principles, standards, and guidelines produced by the spp had different impacts on various subjects. Mainly, they organized operations of the three governments and their bureaucracies. Sometimes, indirectly, they also influenced particular sectors of the economy (steel, energy, the illegal market of counterfeits, airlines) or society (passengers, commuters, counterfeiters of goods). They rarely trans- 
formed the way people in the three countries live (for example, consumers of electronic goods could buy washing machines and TV sets produced according to a common North American standard). Often, they had only a temporary effect, such as with populations affected by natural disasters and pandemics.

The rules promoted in the spP documents were flexible, leaving a lot of room for interpretation, and allowing countries to implement them as they wished. They were general, they were not legally binding, and no sanctions accompanied them. Regulations were limited in scope. The broad agenda only produced a few issues that reached the stage of trilateral policy-making (pandemic and emergency management, intellectual property, energy, regulatory cooperation).

The degree to which the particular spp documents affected the three countries varied. Changes promoted by the spp most often affected Canada and Mexico. Some rules were more vigorously implemented in Mexico, others in Canada. For example Canada did not take intellectual property protection strategy as seriously as Mexico did. On the other hand, Canada and the U.S. were very engaged in common energy policy. Because of constitutional constraints, Mexico could not be as involved in creating and enforcing a common regime of North America.

Only a few topics on the sPp agenda were effectively introduced in the three countries: 1) emergency and public health preparedness, 2) intellectual property protection, 3) regulatory cooperation, and 4) energy. None of these issues were treated exclusively in trilateral negotiations, and even if there was trilateral cooperation, some aspects of these problems were still discussed bilaterally.

Within the spp framework, the North American Strategy for Pandemic Influenza was developed and announced for the first time in 2007 and the second time in 2012. Bureaucrats also developed the North America approach to bovine spongiform encephalopathy (BSE) in 2005. Along with the U.S. and Canada, Mexico and the U.S., and Mexico and Canada updated old bilateral protocols and agreements and negotiated new ones. Based on these commitments, new networks of researchers, first responders, and public safety agencies formed and, in cases of crisis, cooperated. This occurred during the swine flu outbreak in Mexico when laboratories from Canada and the U.S. assisted the Mexican government and counterparts in the diagnosis and development of a vaccine.

The Intellectual Property Action Strategy was negotiated in 2006 and declared in 2007 at the Montebello Summit as one of the spP accomplishments (Pedrero, 2006). In Mexico, it was taken very seriously, and the government started to implement the National Agreement against Pirated Goods and the Usurpation Plan (Procuraduría General de la República, n.d.). Law enforcement and customs agents received training from their U.S. counterparts about identifying fake goods. The issue of counterfeit 
products was raised in public educational programs, and awareness-raising campaigns were launched in 2007 and 2008. The programs increased detection and acquisition of pirated goods, and consumption of illegal software dropped slightly (Lombera 2008a and 2008b; El mañana, 2007).

Regulatory cooperation definitely had more influence on the way regulatory institutions perform in the three countries than on their citizens. Within the SPP, bureaucrats worked on general norms to guide regulatory practices bilaterally and trilaterally. In 2007, the first trilateral document was announced by the leaders: the Regulatory Cooperation Framework. The following year, the officials collaborated further to establish the principles of their regulatory coordination. As a result, they produced three documents: the Common Regulatory Principles, the Initial Work Plan Regulatory Cooperation Framework and the Illustrative Inventory of Best Practices. As a consequence of these efforts, transnational networks of agencies from the three countries were solidified and the practice of early alert became routine. Broad discussions about harmonization were undertaken, and some were more successful than others (for example, negotiations about universal pesticides standards produced no results).

Nevertheless, in some cases, the harmonization of regulations worked. Examples include the Harmonized Air Navigation Systems; an arrangement on the Use of Care Symbols on Textiles and Apparel Goods Labels; reciprocal recognition of containers used for the transportation of dangerous goods; energy performance standards for key household appliances and consumer products, such as freezers, refrigerators, and room air conditioners; harmonization of standards in accordance with the World Organization for Animal Health to allow for the export of Canadian and U.S. American breeding cattle to Mexico.

Regulatory cooperation is still a high priority for North America because it is understood as the main measure for creating greater competitiveness and freer trade in the region. The spr laid a foundation for this collaboration, which was necessary for more specific and sector-oriented talks. Economic regulatory cooperation was carried by trilateral and bilateral working groups and resulted in the signing of two documents: the Common Regulatory Principles in 2007 and the Regulatory Cooperation Framework in 2008. After the SPP stopped operating, Canada and the United States, as well as Mexico and the United States, created separate Regulatory Cooperation Councils.

The subject of energy security and the continental market was discussed trilaterally within the SPP. These discussions produced the Trilateral Agreement for Cooperation in Energy Science and Technology, signed in 2007 and entering into force the same year. On the bilateral level, the United States and Canada signed an agreement that was a milestone in pipeline regulatory cooperation. It increased compliance with data sharing, staff exchanges, and joint training. In turn, the United States and 
Mexico formalized their clean energy and climate change agreements in 2009, but these cannot be included as part of the spp deliverables.

The sPr had an impact on trade liberalization and the organization of the NAFTA economic space because it speeded them up, according to Ministry of the Economy officials interviewed. Negotiations took place related to new NAFTA rules of origin, changes introduced in 2005 that covered approximately US $\$ 30$ billion in annual trilateral trade. An additional set of changes, agreed to in 2007, reduced export-related transaction costs by approximately US $\$ 100$ billion in annual trilateral trade. Here the SPP was not a source of normative change because the talks were part of an ongoing process programmed by NAFTA. However, the SPP framework, with pressure from the chief executives' offices, pushed the bureaucrats to advance quickly in their negotiations.

\section{Conclusion}

This article focuses on the policy-making process mechanics and dynamics, in contrast to other publications that present interests and divergent policy visions as explanatory variables of regional integration in North America, in order to enrich and complement the existing literature. Therefore, it does not give straightforward answers to the questions of which issues on the agenda are more prone to regionalization because of converging interests. On the contrary, it puts the emphasis, inspired by Leon Lindberg's theories, on the makings of the policy at the regional level, to predict whether there will be further policy and political integration within the past and current bureaucratic structures of regional cooperation. In consequence, this analysis argues that the SPP as a management framework tried to overcome the deficiencies of previous management arrangements, as well as of dual bilateralism. It produced mixed outcomes and results for North American regionalism.

Although, thanks to certain organizational innovations and principally its hybrid nature (networked and hierarchical organization), the spp was temporarily able to boost the efficiency and effectiveness of regional cooperation and policy making, it did not leave lasting marks on the regional governance landscape. To some extent, its operational principles enabled politicians and bureaucrats to proceed more quickly and in a less politicized fashion, but only during the first year of its existence (2005 / 2006), and in a certain few issue areas (for example, pandemic threats, e-commerce, border infrastructure, protection of intellectual property).

As the article demonstrates, the weaknesses in the sPP management framework, its broad and ambiguous agenda, and the lack of adequate evaluation and monitor- 
ing to assess progress curbed its chances of success in the form of expanding policy integration and lasting political integration of the region.

At the same time, it was proved that Mexico, the U.S., and Canada addressed different elements of the spp agenda (problems and objectives) in varied ways (intensified communication, temporary cooperation, joint regulations, durable policy changes). It is difficult to determine that some issues always fostered trilateral cooperation and others were treated exclusively bilaterally. Often general principles in some policy area were approached at a trilateral level and details or concrete initiatives were developed bilaterally.

The sPP functioned as a communication/cooperation device that facilitated interactions and joint programs and promoted dialogue in the region in times of conflict and temporary crisis.

The other role of the spp was as a governance mechanism, a forum for developing new rules, principles to organize and govern intergovernmental relations, and, to a much lesser extent, the way people lived in North America. The governance practices retained a lot of autonomy in each of the three countries in terms of how they implemented general guidelines produced by the SPP. It also maintained the new regionalist character of North America by promoting the combination of U.S. multilaterally and trilaterally originated norms.

As far as the regional project in North America is concerned, the Security and Prosperity Partnership exposed the fact that integration driven by the bureaucrats is not going to succeed in producing greater policy and political integration. This type of regionalism is characteristic to the North American space, and the SPP is merely a continuation of the three governments' old habits and patterns of management practices. It leads to the conclusion that strong obstacles of a cultural, social, and political nature must exist that cannot be overcome by the bureaucrats and politicians.

It can also be argued that due to the disruptions and inconsistencies inherent to the national bureaucracies (due to the election cycles and domestic politics), dialogue and cooperation can suffer some discontinuities -as a result, creating joint policies and strategies, creating broader consensus about North America can take a lot of time and energy-; therefore, it would be very difficult to build and acquire the common vision, ideals, and principles necessary for deeper regional integration.

The spe also showed that as a regional governance mechanism (specifically network structures of working groups), it was very weak in producing lasting effects due to the lack of proper resources, dependence on domestic enforcement measures, and poor monitoring. This leads to the conclusion that a North American model of regionalism without greater institutionalization will not be a stable and continuous process toward policy integration on a regional scale. It will be a chain of sporadic 
incidents of greater cooperation and policy convergence in specific issue areas when the priorities and interest converge between the top echelons of power in the three countries, separated by longer periods of diplomatic exchanges calculated to maintain the relationship.

\section{BIBLIOGRAPHY}

ACKLESON, J., and J. KASTNER

2006 "The Security and Prosperity Partnership of North America," The American Review of Canadian Studies, vol. 36, no. 2, pp. 207-232.

Alba, F., J. F. Prud' homme, and Gustavo Vega Cánovas, eds.

2007 Integración en América del Norte: diálogo, cooperación e instituciones, Mexico City, El Colegio de México.

\section{AlmazÁn GonZÁlez, J. A.}

n.d. "El petróleo y la electricidad en el ASPAN," La Jornada, http:/ / www.jornada. unam.mx / ultimas / especiales / casa-lamm/mexico-y-el-mundo-actual / por tada/la-arremetida-calderonista-para-privatizar-el-petroleo-y-la-electricidad/ la-arremetida-calderonista-para-privatizar-el-petroleo-y-la-electricidad/el -petroleo-y-la-electricidad-en-el-aspan, accessed January 12, 2013.

2007 “ASPAN: riesgo para México," La Jornada, March 22, http://www.jornada .unam.mx / 2007/03/22/index.php?section=opinion\&article=026a2pol, accessed January 12, 2012.

ANDERSON, G.

2008 “The Institutions of NAFTA," Norteamérica, year 3, no. 2, pp. 11-41.

Anderson, G., and CH. SANDS

2007 Negotiating North America: The Security and Prosperity Partnership, Washington, D.C., White Paper, Hudson Institute, http: / / hudson.org/files / pdf_upload/ hudsonnegotiatingnorthamericaadvanceproof2.pdf, accessed January 12, 2012.

Arley Orduña, A. M.

2012 "Más allá del TLCAN a negociar mediante la ASPAN. After NAFTA: To Negotiate through the spe," Anuario Mexicano de Derecho Internacional, Décimo Aniversario, Mexico City, Instituto de Investigaciones Jurídicas (IIJ)-UNAM, pp. 317-372. 
Aspe, P., W. F. Weld, and J. P. Manley

2005 Building a North American Community, New York, Council on Foreign Relations.

AYRES, J., and L. MACDONALD

2012 "Democratic Deficits and the Role of Civil Society in North America: The SPP and Beyond," in J. Ayres and L. Macdonald, eds., North America in Question: Regional Integration in an Era of Economic Turbulence, Toronto, University of Toronto Press, Chapter 12.

BAiley, J., and T. Guillen Lopez

2009 Process Management in the U.S.-Mexico Relationship, UCSD, San Diego, Mexico City, Woodrow Wilson Center / Colmex/Colef.

BARLOW, $\mathrm{M}$.

2005 "Why the Waco Pact Is, Well, Wacko," The Globe and Mail, March 26, http:/ / theglobeandmail.com / commentary / why-the-waco-pact-is-well-wacko / article4300742/ ?service $=$ mobile, accessed January 12, 2012.

n.d. "Behind Closed Doors, What They're Not Telling Us about the Security and Prosperity Partnership of North America 2007," Council of Canadians, http: / / www.canadians.org / integratethis / backgrounders / guide / Be hind\%20Closed\%20Doors.pdf\#.UdzJKb-5Mah, accessed January 12, 2013.

BARRY, DONALD

2003 "Managing Canada-US Relations in the post-9/11 Era: Do We Need a Big Idea?" CSIS Policy Paper on the Americas 14, Center for Strategic and International Studies, Washington D.C.

\section{BELANGER, L.}

2010 "Governing the North American Free Trade Area: International Rule-making and Delegation in NAFTA, the SPP, and Beyond," Latin American Policy, vol. 1, no. 1, pp. 22-51.

Benítez Manaut, R., and A. Hristoulas

n.d. "Las relaciones de seguridad entre México y Canadá," Estudios Canadienses, ITAM, http: / / estudioscanadienses.itam.mx/docs/relaciones_seguridad_mexico -cad.pdf, accessed January 12, 2013. 
Benítez Manaut, R., and C. Rodríguez Ulloa

2005 "Seguridad y fronteras en Norteamérica: del TLCAN a la ASPAN," Colombia Internacional, no. 61, January-June, pp. 78-96.

BEVIR, M.

2012 Governance: A Very Short Introduction, Oxford, Oxford University Press.

BIETTE, D., and E. HEARD

2002 Toward a North American Community? A Conference Report, Washington, D.C., Woodrow Wilson International Center for Scholars.

BRoDie, J.

2012 "The Security and Prosperity Partnership: The Short History of a Strategic Bargain," in J. Castro Rea, ed., Our North America, Edmonton, University of Alberta Press.

2008 "The Last Hurrah? The Security and Prosperity Partnership and North America Governance," Revista Mexicana de Estudios Canadienses, no. 16, pp. 16-32.

CÁmara de Diputados

2006 Diario de los debates, LX Legislatura, October 4, http: / / cronica.diputados.gob .mx/PDF / 60/2006/ oct/061004.pdf, accessed January 12, 2013.

CÁmara de Diputados, Centro de Documentación, InFormación y AnÁlisis

2010 "Acta de la sesión ordinaria celebrada el martes veinte de abril 2010."

2008 Comisión de Relaciones Exteriores, Anexo 1: Desglose de reuniones de trabajo; Comisión de relaciones exteriores; Informe de actividades del segundo año de ejercicio de la LX Legislatura, September 2007-August 2008.

2007 Comisión de Relaciones Exteriores, Primer informe de actividades, August 31.

2006 Alianza para la Seguridad y la Prosperidad de América del Norte, 2006.; Diario de los debates LX Legislatura, October 4, 2006.

\section{Canadian Council of Chief Executives}

2003 The North American Security and Prosperity Initiative: Background, Questions and Answers, Canadian Council of Chief Executives, http:/ / www.ceocoun cil.ca/wp-content/uploads/archives/presentations_2003_03_01.pdf, accessed January 12, 2012. 
CAPling, A., and K. Richard Nossal

2009 "The Contradictions of Regionalism in North America," Review of International Studies, vol. 35, pp. 147-167.

Celorio, $\mathrm{M}$.

2005 "The Current Debate Regarding the spr: Security and the Integration of North America," Working Paper, Center for North American Studies, http:/ / www.american.edu/sis/cnas/upload/workingpaper2_celorio.pdf, accessed January 12, 2013.

CÉspedes, E.

2008 "North America, Security, and the Next US National Security Strategy: A Reflection," Working Paper, Center for North American Studies, http:/ / www.american .edu/sis/cnas/upload/0804Cespedes_Reflection.pdf, accessed January 12, 2013.

Chambers, E. J., and P. SMith, eds.

2003 NAFTA in the New Millennium, San Diego, Center for U.S.-Mexican Studies, University of California.

Chaput, D.

2007 Standing Committee on Health Evidence, Parliament of Canada, http:// www.parl.gc.ca / HousePublications / Publication.aspx?DocId=3000577\&Lan guage $=$ E\&Mode=1, accessed December 20, 2012.

CHASE, S.

2011 "Sorry Amigo: Wikileaks Shows Canada Prefers Meeting U.S. without Mexico," The Globe and Mail, March 2.

CLARKSON, S.

2008 Does North America Exist?: Governing the Continent after NAFTA and 9/11, University of Toronto Press.

Clarkson, S., and M. BANDA

2004 Does nAfTA Plus Have a Common Denominator? The Prospects for Mexico and Canada Achieving a Joint Position on Deepening North America? University of Toronto, http://homes.chass.utoronto.ca/ clarkson/publications / Does $\% 20$ NAFTA $\% 20$ Plus $\% 20$ Have $\% 20$ a\%20Common $\%$ 20Denominator $\% 20-\%$ 20The $\%$ 20Prospects $\% 20$ for $\%$ 20Mexico $\% 20$ and $\% 20$ Canada $\% 20$ Achieving $\% 20$ 
a\%20Joint $\%$ 20Position $\% 20$ on $\%$ 20Deepening\% 20North $\% 20$ America.pdf, accessed January 12, 2012.

Clarkson, S., and Matto Mildenberger

2011 Dependent America?: How Canada and Mexico Construct US Power, Toronto, University of Toronto Press.

Cofemer (Comisión Federal de Mejora Regulatoria)

2013 folio 1014100000913.

CONGRESSIONAL RECORD

2007 U.S. Government Printing Office, vol. 153, no. 119, p. H8359, http: / / www.gpo .gov / fdsys / granule / CREC-2007-07-24 / CREC-2007-07-24-pt1-PgH8359 / content-detail.html, accessed January 12, 2013.

Congressional ReCord, SEnATE

2008a S5202 June 5.

2008b S4618 May 21.

2007a S7328 June 7.

2007b S4596, April 17.

Corten, Oliver, and Pierre Klein, eds.

2011 The Vienna Conventions on the Law of Treaties: A Commentary, Oxford, Oxford University Press, pp. 37-39 and 211-212.

Cortés CAmpos, JosefinA

2005 "Hacia la profundización de la integración económica de México," in Integración económica y realidad normativa: el caso de México, Mexico City, Porrúa-ITAM-IBERGop.

COUNCIL OF CANADIANS

n.d. "Behind Closed Doors; What They're Not Telling Us about the Security and Prosperity Partnership of North America 2007," http: / / www.canadians.org/ integratethis / backgrounders / guide / Behind\%20Closed\%20Doors.pdf\# .UdzJKb-5Mah, accessed January 12, 2013.

CRAIK, N.

2011 "Bundled Transgovernmentalism: North American Climate Governance and the Lessons Learned from the Security and Prosperity Partnership," Procedia- 
Social and Behavioral Sciences, vol. 14, June, http: / / www.sciencedirect.com/ science/journal/18770428/14/supp/C, pp. 156-166.

DAUDELIN, J.

2003 The Trilateral Mirage: A Tale of Two North-Americas, Canadian Defence and Foreign Affairs Institute, http: / / www.cdfai.org/PDF/The\%20Trilateral\%20Mirage .pdf, accessed January 12, 2012.

De la Reza, G. A., ed.

2004 México más allá del TLCAN: competitividad y diversificación de mercados, Mexico City, UAM-Plaza y Valdés.

Department of Finance Canada

2008 Budget, http:/ / www.budget.gc.ca/2008/ plan/chap4b-eng.html, accessed January 16, 2013.

2006 Budget, http:/ / www.fin.gc.ca/budget06/bp/bpc3d-eng.asp, accessed January 16, 2013.

DonALD, B.

2003 Policy Papers on the Americas: Managing Canada-US Relations in the Post-9/11 Era. Do We Need a Big Idea? csIS, vol. XIV.

Dorr, O., and K. Schmalenbach, eds.

2012 Vienna Convention on the Law of Treaties: A Commentary, Berlin/Heidelberg, Springer, p. 879.

EPA (Environmental Protection Agency)

2008a "Security and Prosperity Partnership; Notice of Public Meeting," Federal Register, vol. 73, no. 75, April 17, pp. 20920-20923.

$2008 b$ "Modification of the Voluntary Children's Chemical Evaluation Program; Notice of Public Meeting," Federal Register, vol. 73, no. 125, June 27, p. 36513.

ESQUIVEL, J. J.

2005 “Agentes de Bush en México," Proceso, April 4.

Fact Sheet Security and Prosperity Partnership

2005 U.S. Department of State Archive, http://2001-2009.state.gov/p/wha/rt/ SPP/, accessed January 12, 2013. 
FEELEY, JOHN

2009 Scenesetter for President's Obama Visit, July 31, http: / / www.cablegatesearch .net/ cable.php?id=09MEXICO2264, accessed January 12, 2012.

GAFFNEY, JR., F.

2007 "Eroding Sovereignty," Washington Times, August 21, p. A 12.

García-Segovia de Madero, M. T.

2003 "Securing the Parameters of North America: A NAFTA Challenge in a Context of US Unilateralism," Policy Options, Institute for Research on Public Policy, May, http:/ / archive.irpp.org/po/archive/may03/madero.pdf, accessed January $12,2013$.

GiLbert, E.

2007 "Leaky Borders and Solid Citizens: Governing Security, Prosperity, and Quality of Life in a North American Partnership," Antipode, vol. 39, no. 1, pp. 77-98.

GONZÁLEZ AMADOR, R.

2007 "Ceder seguridad y energía, paso siguiente de México en el TLCAN," La Jornada, August 19, http: / / www.jornada.unam.mx / 2007/08/19/index.php?secti on=economia\&article=024n1eco, accessed January 12, 2012.

\section{Government of CANADA}

2008 Budget 2008, Archived- Chapter 4- "Leadership at Home and Abroad Leadership Abroad," http:/ / www.budget.gc.ca/2008/plan/chap4b-eng.html, accessed January 12, 2013.

2007 Joint Statement by Ministers Responsible for the Security and Prosperity Partnership of North America 2007, Government of Canada Security and Prosperity Partnership Archives, http:/ / www.SPP-psp.gc.ca/eic/site/SPP-psp .nsf/eng/00046.html.

2006 Budget 2006, Archived-Chapter 3- "Building a Better Canada Security," http:/ / www.fin.gc.ca/budget06/bp/bpc3d-eng.asp, accessed January 12, 2013.

2005 Security and Prosperity Partnership Report to Leaders 2005, http:/ / www.SPP psp.gc.ca / eic/ site/SPP-psp.nsf/eng/ 00098.html, accessed January 12, 2013.

Grant, R. W., and R. O. KeOHAne

2005 "Accountability and Abuses of Power in World Politics," American Political Science Review, vol. 99, no. 1, pp. 29-43. 
GRONDIN, D., and M. DE LARRINAGA

2009 "Security Prosperity or Making Securitization Prosper? The Security and Prosperity Partnership as North American Biopolitical Governance," International Journal, vol. 64, no. 3, pp. 667-685, Summer.

GUTIÉRREZ FERNÁNDEZ, G.

2005 "La agenda para América del Norte," Revista Mexicana de Política Exterior, no. 73, pp. 9-20.

HAKIM, P., and R. E. LiTAN, eds.

2002 The Future of North American Integration: Beyond NAFTA, Washington, D.C., The Brookings Institution.

HEALY, T.

2007 "North American Competitiveness Council and the spP: Les agents provocateurs at the Montebello Leader's Summit," Research Paper no. 44, Canadian Labour Congress, http:/ / www.congresdutravail.ca/node/451, accessed January 12, 2013.

House OF COMMONS

2007a Standing Committee on Health on June 4, 2007 Evidence, Parliament of Canada, http: / / www.parl.gc.ca/HousePublications / Publication.aspx?DocId=3 000577\&Language $=E \& M o d e=1$, accessed January 12, 2013.

2007b Standing Committee on International Trade on May 10, Evidence, Parliament of Canada, http: / / www.parl.gc.ca/HousePublications/Publication.as px?DocId=2934562\&Language=E\&Mode=1, accessed January 12, 2013.

2007c Standing Committee on International Trade on April 24, Evidence, Parliament of Canada, http: / / www.parl.gc.ca/HousePublications / Publication.as px?DocId=2861332\&Language=E\&Mode=1, accessed January 12, 2013.

Hufbauer, G. C., and J. J. SchOtT

2005 NAFTA Revisited: Achievements and Challenges, Washington, D.C., Institute of International Economics.

HugHES, K. H.

2005 NAFTA at 10: Progress, Potential, and Precedents, vol. 1, Conference Proceedings, Washington, D.C., Woodrow Wilson International Center for Scholars. 
ifai (Instituto Federal de Acceso a la Información y Protección de Datos)

2013a Presidencia de la República, folio 0210000020613, date of answer: March 8.

2013b Presidencia de la República, folio 0210000017013, date of answer: March 1.

2013c Secretaría de Economía, folio 0001000006313, date of answer: February 7.

2013d Secretaría de Economía, folio 0001000005813, date of answer: February 6.

2013e Secretaría de Energía, folio 0001800001113, date of answer: February 5.

2013f Secretaría de Medio Ambiente y Recursos Naturales, folio 0001600007313, date of answer: February 4.

2013g Comisión Federal de Mejora Regulatoria, folio 1014100000913, date of answer: February 4.

2013h Secretaría de Relaciones Exteriores, folio 0000500004913, date of answer: January 31.

2013i Presidencia de la República, folio 0210000115412, date of answer: January 8.

2013j Secretaría de Relaciones Exteriores, folio 0000500160612, date of answer: January 8.

2013k Secretaría de Gobernación, folio 0000400188812, date of answer: January 8.

2012 Secretaría de Economía, folio 0001000154512, date of answer: November 12.

\section{INDUSTRY CANADA}

n.d.a Report on the Trilateral Committee on Transborder Data Flows 2010, http: / / www .ic.gc.ca/eic/site/ecic-ceac.nsf/eng/h_gv00520.html, accessed January 12, 2013.

n.d.b Regulatory Cooperation in the Area of Chemicals, Environmental Protection Agency, http:/ / www.epa.gov/hpv/pubs/general/ SPPframework.htm, accessed January 12, 2013.

Instituto Tecnológico Autónomo de México- Escuela Iberoamericana de

Gobierno y Políticas Públicas (itAm-Ibergor)

2005 Integración económica y realidad normativa: el caso de México: hacia la profundización de la integración económica de México, Mexico City, Porrúa.

JUdicial WATCH

2007a "Security and Prosperity Partnership: Threat or Opportunity Conference Recordings," http:/ / www.judicialwatch.org/archive/2007/JWpanel2.mp4, accessed January 12, 2012.

2007b U.S. Department of Commerce Response. Prosperity Priority of the sPP Points of Contact, Leads of Environmental Agenda, http:/ / www.judicialwatch.org/ archive / 2007 / StateSPPResponseReEnviroAgenda.pdf, accessed January 16, 2013. 
2007c The spp Travel Screening Systems Steering Committee, http://www.judicial watch.org/ archive/2007 / SPPTravelScreeningWG.pdf, accessed January 16, 2013.

2006 The spp Working Group on Electronic Commerce, Information and Communications Technologies Inter-agency Members, http:/ / www.judicialwatch.org/ archive/2006/SPPEComMtg25Apr05.pdf accessed January 16, 2013

Kirton, J., and J. Guebert

2010 "North American Health Governance: Shocks, Summitry, and Societal Support," Norteamérica, year 5, no. 1, pp. 221-244.

LeGORRETA ODORIKA, JORGE

2013 IFAI folio 0001600007313, to be accessed on IFAI portal infomex.gob.mx; response on behalf of SEMARNAT, January 30.

Leycegui GardoQui, B., ed.

2012 Reflexiones sobre la politica comercial internacional de México 2006-2012, Mexico City, Miguel Ángel Porrúa.

LINDBERG, L.

1970 "Political Integration as a Multidimensional Phenomenon Requiring Multivariate Measurement," International Organization, vol. 24, no. 4, pp. 648-731.

LOMBERA, M.

2008a "Empujarán reformas para homologar medición de piratería," El Universal, December 8, http: / / www.eluniversal.com.mx/notas/561365.html.

2008b "Decomisa ImPI piratería por 21 millones de pesos," El Universal, September 19, http:/ / www.eluniversal.com.mx/ notas / 539832.html.

LuO, M.

2007 "Rumors of a Superhighway," New York Times, July 30, http:/ / thecaucus .blogs.nytimes.com/2007/07/30/ rumors-of-a-super-highway/.

\section{EL MAÑANA}

2007 “Frenarán México y EU importación de piratería," August 31, http: / www .elmanana.com.mx/ notas.asp?id=13288, accessed January 13, 2013. 
MARTIN, J. K.

2005 "North American Regulatory Co-operation a Results Agenda: Symposium Report," Ottawa, Policy Research Initiative, December 8.

Martínez Bejarano, María Eugenia

2012 Response vía Portal de Atención Ciudadana, Centro de Investigación sobre América del Norte (CISAN), December 13.

MASSON, STEVEN

n.d. "Upgrading North American Architecture through the Security and Prosperity Partnership," unpublished thesis, https: / curve.carleton.ca/theses/29192, accessed July 20, 2014.

Moens, A.

2011 "Lessons Learned from the Security and Prosperity Partnership for CanadianAmerican Relations," American Review of Canadian Studies, vol.41, no. 4, pp. 53-64.

Morales, I.

1999 "The Governance of Economic Openness," Annals of the American Academy of Political Science, vol. 565, no. 1, pp. 35-65.

NeVAER, L. E. V.

2004 NAFTA's Second Decade: Assessing Opportunities in the Mexican and Canadian Markets, Mason, Ohio, Thomson/South-Western.

Noble, J. J.

2005 "Fortress America or Fortress North America?" Law and Business Review of the Americas, vol. 11, no. 3/4, pp. 461.

Nossal, Richard K.

2010 “Canadian Policy towards Mexico: Pastor's Puzzle Reconsidered," North American Dialogue Series, no.13, http:/ / cedan.ccm.itesm.mx/wp-content/uploads / 2010/08/north_american_dialogue_no13_kim_richard_nossal.pdf, accessed January 12, 2013.

NúÑEZ-García, S., and M. ChÁvez, eds.

2008 Critical Issues in the New U.S.-Mexico Relations: Stumbling Blocks and Constructive Paths, Mexico City, CISAN-UnAm/ CLACs. 


\section{PARTNERSHIP OF NORTH AMERICA}

2006 U.S. Department of State Archives, March 31, http: / / 2001-2009.state.gov / p / wha/ rls / prsrl/2006/ q1 / 69851.htm, accessed January 12, 2013.

PASTOR, R.

2005 "North America: Three Nations, a Partnership, or a Community?" Jean Monnet/Robert Schuman Paper Series, vol. 5, no. 13, http:/ / www6.miami.edu/eu center/pastorfinal.pdf, accessed January 12, 2013.

2001 Toward a North American Community: Lessons from the Old World to the New World, Washington, D.C., Institute for International Economics.

PATRY, B.

2002 Partners in North America. Advancing Canada's Relations with the United States and Mexico Report of the Standing Committee on Foreign Affairs and International Trade, Parliament of Canada, http:/ / www.parl.gc.ca/HousePublications / Publication.aspx? DocId=1032319\&Mode=1\&Parl=37\&Ses=2\&Language=E, accessed January 12, 2013.

PeDRERO, F.

2006 "Se unen los países del TLCAN contra piratería," El Universal, September 25, http:/ / www.eluniversal.com.mx / finanzas / 54058.html.

Preciado Coronado, J.

2009 “Agendas geoeconómicas y geoestratégicas de la Alianza para la Seguridad y la Prosperidad de Norteamérica (ASPAN), cuestionamientos al modelo neoliberal," Investigaciones Geográficas, Boletín del Instituto de Geografía, no. 69, http: / / www.ejournal.unam.mx/rig/ RIG069/RIG000006908.pdf, pp. 113-127.

\section{PROCESO}

2007 “Firman México y EU acuerdo para detectar material radiactivo y nuclear en puertos mexicanos," April 17.

Procuraduría General de la República

n.d. “Campañas Nacionales, Piratería," http:/ / pirateria.pgr.gob.mx/campanas -nacionales.htm, accessed January 12, 2013.

PRUDEN, W.

2007 “The Three Amigos, Erasing Borders?” Washington Times, August 21, p. A 4. 
Roff, R. J., A. KRajNC, and S. Clarkson

2009 The Double Eco-Illogic of North American Governance: NAFTA, Energy Subsidies, and Climate Change, Toronto, University of Toronto, http:/ / homes.chass.uto ronto.ca / clarkson / publications / The $\% 20$ Double $\% 20$ Eco-illogic $\% 20$ of $\% 20$ North $\%$ 20American\%20Governance $\% 20$-\%20NAFTA,\%20Energy\%20Subsi dies,\%20and\%20Climate\%20Change.pdf, accessed January 12, 2013.

Rosenau, J. N., and E. Czempiel, eds.

1992 Governance without Government: Order and Change in World Politics, Cambridge, Massachusetts, Cambridge University Press.

Rozental, A.

2006 "The Security and Prosperity Partnership. An Overview," International Journal, vol. 61, pp. 541-544.

Sandoval Palacios, J. M., ed.

2008 La Alianza para la Seguridad y Prosperidad de América del Norte: nuevo desafío a la nación mexicana, Mexico City, Centro de Estudios Estratégicos de América del Norte.

SANDS, Ch.

2006 "Different Paths Leading from Cancun," csis North American Integration Monitor, vol. 3, no. 2, http:/ / csis.org/files/media/csis/pubs/naim06_05.pdf.

SAVAGE, L. Ch.

2011a “Truckers Cautious about Border Declaration," Maclean's, February 4, http:/ / www2.macleans.ca/2011/02/04/truckers-cautious-about-border-declaration/.

$2011 b$ "U.S. Ambassador David Jacobson Explains the Border Deal," Maclean's, February 4, http: / / www2.macleans.ca / 2011 / 02 / 04 / u-s-ambassador-david -jacobson-explains-the-border-deal.

2010a "The End of North American Trilateralism," Maclean's, June 29, http: / / www2 .macleans.ca/2010/06/29/the-end-of-the-trilateral-dream/.

2010 b "The End of North American Trilateralism," Maclean's, June 29, http: / / www2 .macleans.ca/2010/06/29/the-end-of-the-trilateral-dream/.

2007 "In Search of the NAFTA Highway to Hell," Maclean's, October 8, http: / www .macleans.ca / world / global / article.jsp?content=20071008_110123_110123. 


\section{SeCretaría de ECONOMÍA, Sistema de InFormación Arancelaria}

2007 Security and Prosperity Partnership. Key Accomplishments since March 2006, U.S. General Printing Office, pp. 1095-1097, http:/ / www.gpo.gov/fdsys/pkg/ PPP-2007-book2/ pdf/ PPP-2007-book2-doc-pg1095.pdf, accessed January 12, 2013.

2006a Security and Prosperity Partnership. Report to Leaders 2006, http:/ / www.econo mia-snci.gob.mx/sic_php/pages/publicaciones / pdfs/Report_to_Leaders _August_2006.pdf, accessed January 12, 2013.

2006b Security and Prosperity Partnership. Key Accomplishments since June 2005, March, Prime Minister of Canada Stephen Harper, http:/ / www.pm.gc.ca/eng/media .asp?id=1084, accessed January 12, 2013.

SRE (SECretaría de Relaciones Exteriores)

n.d. http:/ / www.sre.gob.mx/eventos/aspan/convocatoria.htm, accessed December 20, 2012.

TORRES, B.

2005 "Transnational Actors and NAFTA: The Search for Coalitions on Labor and the Environment in Regionalism in the Americas," in L. Fawcett and M. Serrano, eds., Regionalism and Governance in the Americas: Continental Drift, London, Macmillan.

\section{EL UNIVERSAL}

2007 “Firman México y EU acuerdo para detectar material radioactivo," April 16, http:/ / www.eluniversal.com.mx/ notas / 418901.html.

\section{U.S. DePARTMENT OF COMMERCE}

2006a International Trade Administration of the US Department of Commerce Concerning the Security and Prosperity of North America, sec. I, II, III, IV, VI, VIII, September 25, section VI, http:/ / www.judicialwatch.org/archive/2006/ SPPFOIADocsSecVI.pdf; section III, http://www.judicialwatch.org/archi ve/2006/SPPFOIADocsSecIII.pdf; section I, https:/ / www.judicialwatch.org/ archive/2006/SPPFOIADocsSecI.pdf; section V, https:/ / www.judicialwatch. org/archive/2006/SPPFOIADocsSecV.pdf; section VIII, https: / / www.judi cialwatch.org/archive/2006/SPPFOIADocsSecVIII.pdf; section IV, http: / / www .judicialwatch.org/archive/2006/SPPFOIADocsSecIV.pdf; section II http: / / www.judicialwatch.org/archive/2006/SPPFOIADocsSecII.pdf, accessed January 16, 2013. 
2006b The spP North American Pandemic Influenza Preparedness Planning Proposed Focal Points and Working Group Participants, January 24.

2005 Working Group on Electronic Commerce Information \& Communications Chairs Meeting, April 25.

\section{U.S. Department of Commerce Archives}

2008a "Joint Statement by Ministers Responsible for the Security and Prosperity Partnership of North America," http:/ / 2001-2009.commerce.gov/NewsRoom/ PressReleases_FactSheets/PROD01_005282.html, accessed January 12, 2013.

2008b Security and Prosperity Partnership Key Accomplishments since August 2007, April, U.S. Department of Commerce, http:/ / e-learning.commerce.gov/s / groups/public/@doc/@os/@opa/documents / content/prod01_005565.pdf, accessed January 12, 2013.

\section{U.S. EMBASSY IN OtTAWA}

2005a "The SPP: First Financial Services Working Group Meeting Yields Deliverables," October 17, http: / / www.cablegatesearch.net/ cable.php?id=05OTTA WA3103\&version=1314919461, accessed January 12, 2013.

2005b “Trilateral Regulatory Cooperation Meeting under the sPP," December 21, http: / / www.cablegatesearch.net/ cable.php?id=05OTTAWA3726, accessed January 12, 2013.

2005c "Security and Prosperity Partnership in Canada- A Mid-term Update," May 5, http:/ / www.cablegatesearch.net/cable.php?id=05OTTAWA1364, accessed January 12, 2013.

2003 “Canadian CEO's Push 'North American Security and Prosperity' Initiative in Washington DC," April 7, http:/ / www.cablegatesearch.net/cable.php?id= 03OTTAWA443, accessed January 12, 2012.

\section{U.S. GaO (U.S. Government AcCountability OfFice)}

2012 U.S. GAO Report: “Combating Nuclear Smuggling: Megaports Initiative Faces Funding and Sustainability Challenges," Washington, D.C.

2008 U.S. GaO Report: "Various issues led to the termination of the United StatesCanada Shared Border Management Pilot Project," Washington, D.C.

\section{U.S. Government Printing Office}

2006 Foreign operations, export financing, and related programs appropriations Bill 2006, http://www.gpo.gov/fdsys/pkg/PLAW-109publ102/pdf/PLAW 109publ102.pdf, accessed January 12, 2013. 


\section{U.S. General Printing Office Presidential Documents}

2008 "Joint Statement by President Bush, President Calderon, Prime Minister Harper, North American Leaders' Summit April 22 2008," http:/ / www.gpo .gov / fdsys / pkg / WCPD-2008-04-28 / pdf / WCPD-2008-04-28-Pg565.pdf, accessed January 12, 2013.

2007a "Joint Statement by Prime Minister Harper, President Bush and President Calderon North American Leaders' Summit, August 21 2007," pp. 1097-1099, http: / / www.gpo.gov/fdsys/pkg/WCPD-2007-08-27/ pdf/WCPD-2007-08 -27.pdf, accessed January 12, 2013.

2007b "Joint Statement by Ministers Responsible for the Security and Prosperity Partnership of North America," Government of Canada, Security and Prosperity Partnership Archives, http:/ / www.SPP-psp.gc.ca/eic/site/SPP-psp .nsf/eng/00046.html, accessed January 12, 2013.

2005 "Joint Statement by President Bush, President Fox, and Prime Minister Martin: Security and Prosperity Partnership of North America, March 23 2005," http: / / www.gpo.gov/fdsys/pkg/WCPD-2005-03-28/ pdf/WCPD-2005-03 -28-Pg517.pdf, accessed January 12, 2013.

\section{U.S. SENATE}

2009 "Environment, and Related Agencies Appropriations for Fiscal Year 2010," Committee on Appropriations, Department of the Interior, U.S. Government Printing Office, http: / / www.gpo.gov / fdsys / pkg/CHRG-111shrg89104360 / pdf/CHRG-111shrg89104360.pdf, accessed January 12, 2013.

2007 "Commerce, Justice, Science and Related Agencies Appropriations for Fiscal Year 2008," Committee on Appropriations, U.S. Government Printing Office, http: / / www.gpo.gov/fdsys / pkg/CHRG-110shrg33908/pdf/CHRG -110shrg33908.pdf, accessed January 12, 2013.

2006 "US Entry/ Exit Tracking," Committee on Appropriations, U.S. Government Printing Office, http:/ / www.gpo.gov/fdsys/pkg/CHRG-109shrg26743/html/ CHRG-109shrg26743.htm, accessed January 12, 2013.

2005a "Department of Homeland Security Appropriations for Fiscal Year 2006," Committee on Appropriations, U.S. Government Printing Office, http:/ / www.gpo.gov / fdsys / pkg / CHRG-109shrg99863/pdf / CHRG -109shrg99863.pdf, accessed January 12, 2013.

2005b "North American Cooperation on the Border," Committee on Foreign Relations, U.S. Government Printing Office, http: / / www.gpo.gov/fdsys/pkg/CHRG -109shrg28131/pdf/CHRG-109shrg28131.pdf, accessed January 12, 2013. 
VAN LANDINGHAM, R. CH.

2009 "Do We Have an Agreement? Examining the Constitutionality and Legality of the Security and Prosperity Partnership of North America and the Legal Ramifications of its Informality," Pennsylvania State International Law Review, vol. 27, no. 3/4, pp. 937.

Vega CÁnovas, G.

2010a El Tratado de Libre Comercio en América del Norte: visión retrospectiva y retos a futuro, Mexico City, El Colegio de México.

2010b El Tratado de Libre Comercio de América del Norte. Génesis, auge, crisis y desafíos al futuro, Cuadernos del Consejo Mexicano de Asuntos Internacionales, Mexico City, Comexi.

2005 "Regional Governance. The Case of Dispute Settlement in NAFTA," in L. Fawcett and M. Serrano, eds., Regionalism and Governance in the Americas: Continental Drift, London, Macmillan.

VelázQuez Flores, Rafael, and J. A. Schiavon

2008 “El 11 de septiembre y la relación México-Estados Unidos: ¿hacia la securitización de la agenda?," Revista Enfoques: Ciencia Política y Administración Pública, vol. 6, no. 8, pp. 61-85.

VILLIGER, M. E.

2009 Commentary on the 1969 Vienna Convention on the Law of Treaties, Boston, IDC/ Martinus Nijhoff, pp. 77-79.

WeINTRAUB, S., ed.

2004 NAFTA's Impact on North America: The First Decade, CSIS.

White House

n.d. North America, http:/ / www.whitehouse.gov/omb/oira_irc_north_america, accessed January 12, 2013.

WIKILEAKS

2009 Cable reference: \#09Mexico2264, http:/ / wikileaks.rsf.org/ cable/2009/07/ 09MEXICO2264.html, accessed January 13, 2014.

2005a Cable \#05Ottawa3726, 2005, dated December 21, titled TRILATERAL REGU LATORY COOPERATION MEETING, https: / / wikileaks.org/cable/2005/ 12 / 05OTTAWA3726.html, accessed February 12, 2013. 
2005b Cable\#05Ottawa3103, dated November 17, 2005, titled SPP: FIRST FINANCIAL SERVICES WORKING GROUP, https: / / wikileaks.org/cable/2005/10/ 05OTTAWA3103.html, accessed February 12, 2013.

2005c Cable \#05Ottawa1364, 2005, dated May 5, 2005, titled Security and Prosperity Partnership in Canada - A, https: / / wikileaks.org/ cable/2005/05/ 05OTTAWA 1364.html, accessed February 12, 2013.

2003 Cable reference: HOMELAND SECURITY FOR EPR (BROWN), https: / wi kileaks.org/cable/2003/02/03OTTAWA443.html.

ZAMORA, S.

2011 "Rethinking North America: Why NAFTA's Laissez Faire Approach to Integration Is Flawed, and What to Do About It," Villanova Law Review, vol. 56, pp. 631-670. 